\title{
PROF. ENDES PONGRÁC ÉLETE ÉS MUNKÁSSÁGA VISSZAEMLÉKEZÉS SZÜLETÉSÉNEK 110. ÉS HALÁLÁNAK 25 ÉVES ÉVFORDULÓJÁRA
}

\begin{abstract}
The Life and SCIENTIfic Career of PRof. ENDES Pongrac: In Memoriam of His $110^{\text {Th }}$ Birthday, and THE 25 $5^{T H}$ ANNIVERSARY OF HIS DEATH. The study reminisces on the life and work of Prof. Pongrác Endes, through the account of the author who was a colleague and student of Endes. Professor Endes had been a dominant figure of the field of pathology at the Faculty of Medicine of the University of Debrecen for a number of years. He became a legend even before his death, and a number of anecdotes circulated about his expertise. The study is based on the presentation of the author, adjured by the Hungarian Society for the History of Medicine, and the Professor's Club of the University of Debrecen, to celebrate the dual anniversary of Professor Endes. The presentation includes bibliographical details, in addition to interesting scientific and educational information. The tone of the study clearly indicated that the Master and student relationship between Professor Endes and the author turned into a friendship over the years.
\end{abstract}

Endes Pongrác hosszú éveken keresztül a Debreceni Egyetem Orvoskarának (anno „DOTE ${ }^{1 ”) ~ m e g h a t a ́ r o z o ́ ~ e g y e ́ n i s e ́ g e, ~ a ~ m a g y a r ~ p a t h o l o g i a ~ d o m i n a ́ l o ́ ~ s z a k t e k i n t e ́ l y e ~}$ volt, akit már életében is szájról szájra terjedő színes anekdoták, esetenként szinte legendák öveztek. A kettős évforduló alkalmával a Magyar Orvostörténeti Társaság és a DE Professzori Klub felkérése (úm. tartsak előadást Endes professzor úrról) lehetőséget adott arra, hogy első (és életem későbbi időszakát döntően meghatározó) Mesterem életéről, személyéről nyilvánosan gondolkodjak. Az előadás hangnemét meghatározta és ennek az írásnak sok részletét is óhatatlanul áthatja az a tény, hogy a kezdeti Mestertanítvány viszonyból idővel barátság alakult ki. Ez az állítás a korkülönbség miatt meghökkentő, de kapcsolatunk ilyetén meghatározása Endes professzor úrtól származik. ${ }^{2}$

Írásom követi az előadás logikáját, sok esetben szó szerinti idézeteket is átvettem annak anyagából. Ezt fontos megemlítenem, mert az előadás meghallgatható az interneten, ${ }^{3}$ így a korábban elmondottak jól kiegészítik ezt az írást. Korábban is, most is elsősorban személyes emlékeimre támaszkodom. „A debreceni orvosképzés nagy alakjai” c. sorozat 18. füzetében (DE-OEC, 2005) Endes professzor úrról képekkel és irodalomjegyzékkel ellátott részletes visszaemlékezést írt későbbi tanszéki utóda, dr. Gomba Szabolcs. Kettőnk elkerülhetetlenül eltérő megközelítése miatt a két írás összevetése árnyaltabb képet ad Endes Pongrácról.

\footnotetext{
${ }^{1}$ Debreceni Orvostudományi Egyetem. Alapjában oximoron: a klasszikus értelemben vett Universitas egy karra szükítése.

${ }^{2}$ Lásd lentebb.

${ }^{3}$ https://www.youtube.com/watch?v=ofSoHs3tenA (letöltés: 2018. augusztus 1.).
} 
Sok helyen hivatkozom Ottlik Gézára, illetve idézem írásait. Ennek magyarázata kettős: Az „Iskola a határon” Endes Pongrác egyik kedvenc olvasmánya volt, amit másokkal is elolvastatott (erre még visszatérek). Kenyerem javát megettem, mire valamelyest megértettem ezt a regényt, amit hozzáértők nemcsak a XX. század magyar, hanem világirodalmában is meghatározó jelentőségűnek tartanak. Ebben nagy segítségemre voltak Fűzfa Balázs és munkatársainak munkái. ${ }^{4}$ Az előadás szerkesztésekor, csakúgy, mint írás közben is támaszkodom Balázs számtalan gondolatára. Egy rögtön idekívánkozik: "mert a megirással menthetetlenül elveszik valami, s akár felismerhetetlenné válhat a valóságos történet úgy, ahogy volt". Az olvasóra bízom, hogy saját tapasztalatait figyelembe véve töprengjen ennek az állításnak mélységes igazán. Írásom értelmezésében Ottlik egy gondolata segíthet: „Nem tudom kifogástalan idörendbe szedni az eseményeket. Pedig szeretném. Igaz ugyan, hogy mindez s még sok más is, amit majd el kell mondanom, egyszerre volt érvényes, egy idöben."

Függetlenül attól, hogy ezt megfogalmazzuk-e magunk számára (netán ki is mondjuk), mindannyian éljük és átéljük, hogy az idő csak a fizikában (és ott sem mindenütt) lineáris. Életünk során számtalan dimenzióban hurkolódó, visszafelé is ható csoda az idő, ami értelemszerủen Endes Pongrác személyiségének kialakulására is így hatott. Ottlik műveinek olvasásakor, de Endes életének elemzésekor is világossá válik, hogy az első pillanatban paradoxonként ható állítás igaz: a múlt nem minden metszete rögzített valóság. Az előadás és ez az írás is felettébb szubjektív, és elkerülhetetlenül keverednek benne idősíkok: amikor Endes professzor úr („Endes”, az „Öreg”, a „Prof.”) személyiségéről próbálok képet adni, akkor az olvasottak, hallottak, átéltek, sokszor pontatlan - nyilván az elmúlt évek csorbult prizmáján áttűnő - emlékek összessége tükröződik a leírtakban. NB. Az író egyik lenyűgöző teljesítménye, ahogy az „Iskola” lapjain prousti vagy éppen joyce-i bravúrral bánik az IDÓ-vel.

Mielőtt belebonyolódnék az idő ontológiai vagy episztemológiai elemzésébe, a múlt egy rögzített pillanatát idézem: Endes Pongrác 1907. december 12-én született Budapesten. Édesanyjáról a hivatalos adattárban (Zeneakadémia) ${ }^{5}$ az alábbiakat találtam:

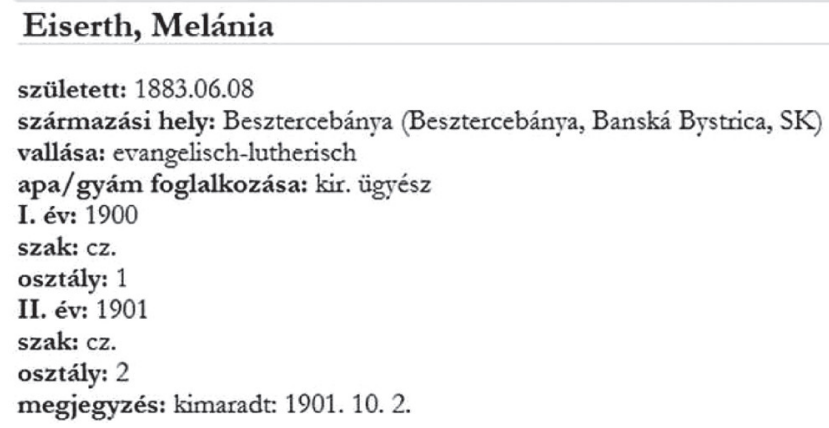

${ }^{4}$ FüZfa Balázs, Kifelé a ködböl. Írások Ottlik Géza müveiröl (Szombathely, 2017).

${ }^{5}$ http://leveltar.elte.hu/databasesnew.php?ekod=93 (letöltés 2018. augusztus 1.). 
Melánia karcsú, magas, szellemes, vidám, a hagyomány szerint „meghatározó társasági lény” volt, Kacsóh Pongrác vezette be a pesti „nagyvilági” életbe. Így ismerte meg Kisfaludi Strobl Zsigmond, akit megragadott a leány szépsége és szobrot készített (a családi hagyomány úgy tartja, hogy széken állva) a művésznőről. A szobrot Endes professzor úr szobájában sokszor megcsodáltam. Abban az időben, mikor gyakorta ott lakva őriztem a lakást, nem tudtam, hogy kit ábrázol. Az emlékelőadásra készülve kerestem meg Endes Mihályt és nála láttam újra a szobrot, illetve hallottam a történetét.

Melánia és Kacsóh Pongrác viszonyáról részleteket nem ismerünk. A zene feltehetően kapcsolódási pont lehetett, miután Melánia 1900-1902 között a Zeneakadémia hallgatója volt. Nem meglepő, hogy Melánia szépsége és személyisége a zeneszerzőt is megragadta.

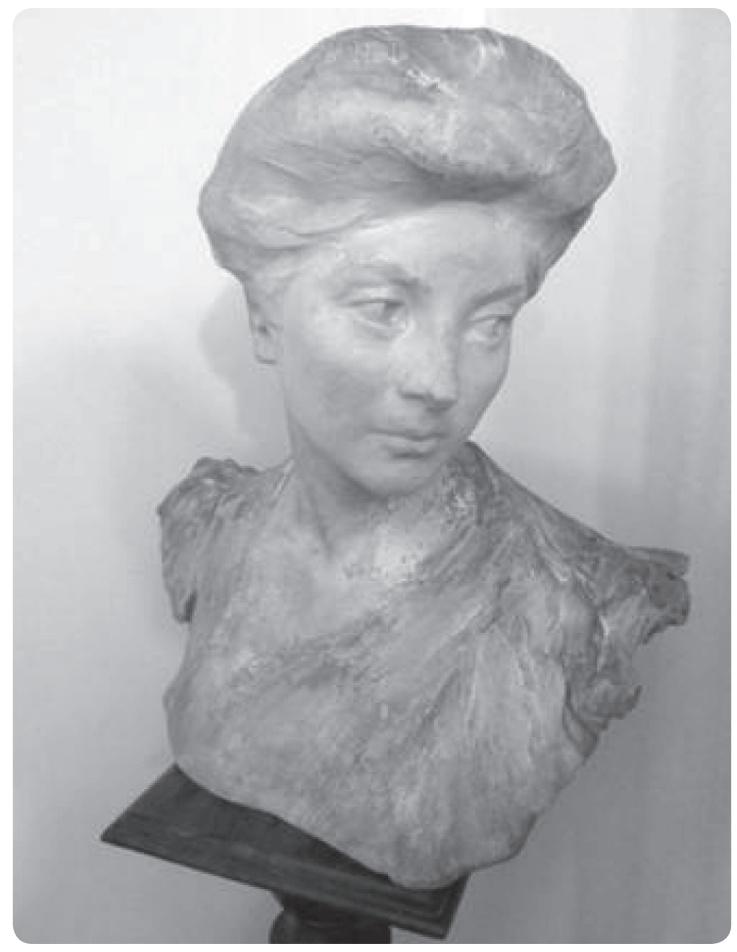

Kacsóh Pongrác kivételes személyiség volt, akinek jellemzésére csak egy részletet idézek a róla megjelent írásokból: "Szenvedélyesen szereti az életet. Baráti társaságokban, összejöveteleken sodró, pezsgö habitusával valósággal felvillanyozza baráti körét, vagy hallgatóságát. Mondják, tanitani, nevelni is ilyen szenvedélyes hevülettel égett az órákon. Magyarázataival, gyakorlatias példáival sokszor elbüvöli hallgatóságát, amely pedagógiai szemlélet nem korlátozódik matematika-és fizikaóráira, átterjed zenei nevelésére, a zene

\footnotetext{
${ }^{6}$ http://www.szineszkonyvtar.hu/contents/k-o/kacsohelet.htm (letöltés: 2018. augusztus 1.).
} 
iránti szeretet hallgatóságában való felgyújtására. Elöadásokat tart szinte mindenütt, ahol csak teheti, ahol a hallgatóság érdeklödésének csak a kis szikrája is érzékelhetö, így többek között az akkori Német utcában müködö, úgynevezett Erzsébet Népakadémián is. Hosszan és szenvedélyesen beszél arról, hogyan hallgassunk zenét, milyen az a zene, amelynek hallgatásával fejleszthetjük zenei izlésünket, milyen érzéseket fejezhetünk ki zenével. Sikraszáll a giccs-zene ellen, és egyik elöadásában ezzel kapcsolatosan a következöket mondja: „A közönséges muzsika rosszabb a krajcáros, piaci versfüzetnél, az olajnyomatnál és a gipszfiguránál, mert mélyebben hinti el mételyét a lelkekben, tehát káros hatása nehezebben orvosolható."”
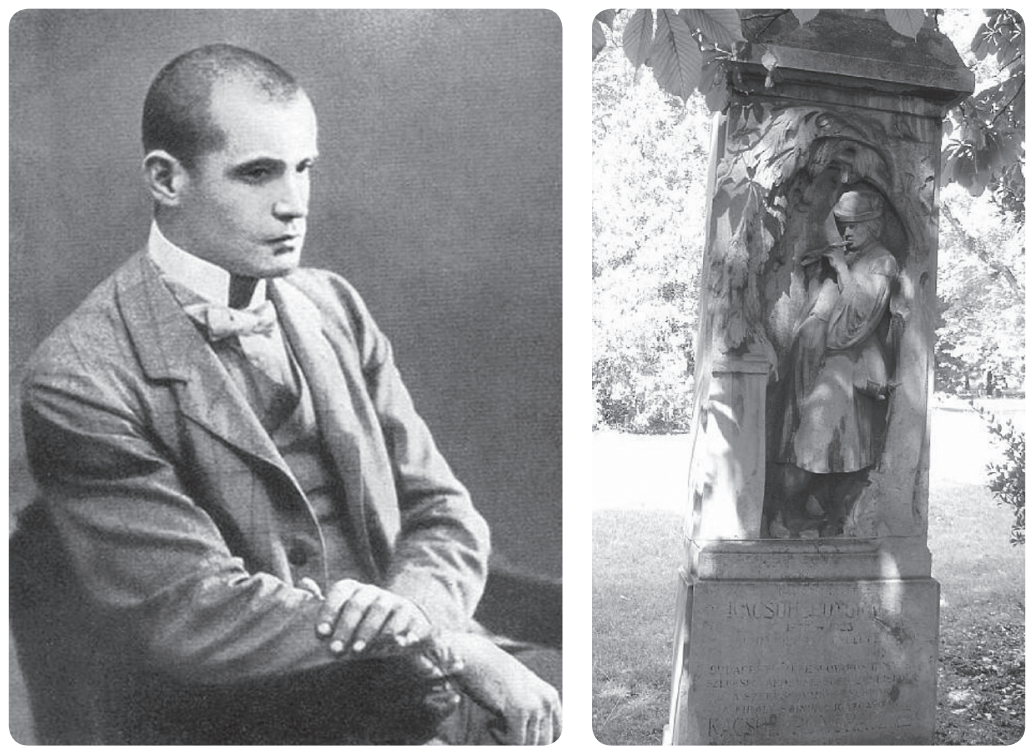

Kacsóh Pongrác képe és sirremléke

A zene szeretetét fia is örökölte, de kézzelfoghatót gyakorlatilag nem kapott édesapjától, aki nevét nem adta fiának, magára hagyta édesanyjával, akit hatéves korában elveszített. Ez a kettős trauma élete végéig kísérte, meghatározó volt személyiségének alakulásában. Apja kiszámíthatatlan időpontokban, ritkán kereste fiával a kapcsolatot. Az utolsó konkrétum, amiről fiai tudnak, egy ezüst kétkoronás, amit az apa frissen érettségizett fiának küldött. Nekem egy alkalommal tett említést néhány kurta levelezőlapról, amit hébe-hóba az apjától kapott. Keresztneve élete végéig kellett, hogy emlékeztesse erre az eltaszítottságra. A sors bizarr fintora, hogy Kacsóh Pongrác egyik dédunokája (dr. Endes Mihály fia) találkozott a törvényes házasságából származó fiú, marossélyei dr. Kacsóh János egyik gyermekével. E találkozás részleteiről bővebbet nem tudok. 
Édesanyja halála után anyai nagymamája vette magához, Felsőpulyára. ${ }^{7}$ Keserves évek következtek, a nyomornak (hivatalosan is dokumentált) olyan mértéke, amit a többség (szerencsére) csak legfeljebb Móra Ferenc írásaiból ismer. Facipőben kellett járnia és sokszor éheztek („Gráci, nincs vacsora. Menj az erdöbe, szedj gombát, akkor tudunk enni valamit"). A gombák azonosítása nem mindig sikerült, előfordult, hogy a szükségvacsorát gyomorrontás követte, de nagyobb baj nem történt.

Nehéz rekonstruálni és pontosan tisztázni ennek az időszaknak az eseményeit. Keveseknek és ritkán beszélt életének erről a szakaszáról. Tanulmányait a kőszegi „Ferenc József Katholikus Főgimnázium” falai között folytatta.

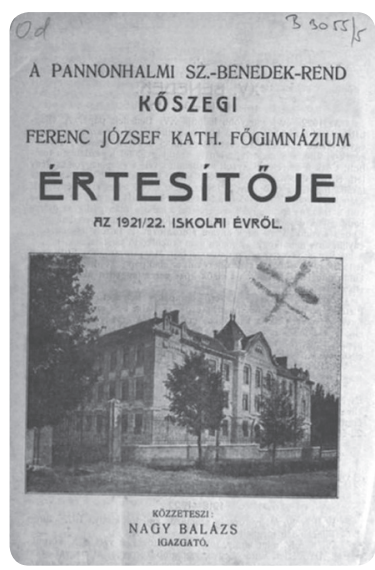

\section{v. osztály,}

Albek Ferenc jó, Balics Aladár jó, Balics József jeles, Belsõ Ferenc jeles, Beyer Ottó ág. h. ev. jó. Bodó Károly elégséges, Eiserth Pongrác jó, Endrédi Géza elégséges, Gabriel Lajos jó, Gombóc Lipót jeles, Hajdu Gyula elégséges, Hajdu Zoltán elégséges, Hegedüs Jenỏ latin, Illa Dénes elégséges, Jaross Nándor jeles, Kamarás Pál elégséges, Kapuy László elégséges, Martincsevits László latin, Potyi Gyula jó, Pusztay Mihály elégséges, Riedinger Pál jeles. Schneider János elégséges. Stubenvoll Károly jeles, Szerdahelyi Jenô elègséges, Szomor Barnabás elégséges, Szovják László latin Tahin Gyula jeles, Hendrich Adolf ism., nem ismételhet.

Magántanulók: Kelemen Ferenc elégséges, Loparits József elégséges, gr. Széchenyi Miklós elégséges, Tax E. Gerarda jó.

Kimaradtak: Mersich János, Schitzhofer Frigyes. Osszesen : 34.

Ez az időszak biztosította, hogy az Ottlik tollából sokkal később (1959) megszületett „Iskola a határon” légköre, a szereplők között fonódó viszonyrendszer, a hierarchikus szinteken belüli, illetve a szintek közötti konfliktusok, a falakon belül szövődő és a határokon átnövő, rendkívül szerteágazó emberi kapcsolatok világa alapvetően ismerős volt Eiserth Pongrác számára. A regényből megismerhető kőszegi atmoszféra (éppen a regény idejében) saját ifúk korát kellett idézze. Nemcsak a város, de környezete is örökre bevésődött az emlékeibe. 1985-ben, egy interjúban azt mondta: „Még ma is álmodom a köszegi hegyekkel."

Evangélikus háttérrel, nagyon szegény gyermekként érkezett a katolikus gimnáziumba. Nincs konkrét tudásunk arról, hogy milyen nehézségekkel kellett megküzdenie a beilleszkedés során, de a regény bőséggel ad támpontot annak elképzeléséhez, hogy mi történhetett a szülei elvesztését követően eleve sérülékeny fiúval, egy, a regényben leírtaknak fizikai valóságában oly sok mindenben megfelelő bencés intézményben. ${ }^{9}$

\footnotetext{
${ }^{7}$ Ma Oberpullendorf, Ausztriában.

8 „Az én katedrám”, interjúsorozat, Egyetemi Élet, 1985. március 26.

9 A különbség világos: a Ferenc József Főgimnázium nem volt katonai iskola, de szigorú rendszere sokban hasonlíthatott egy ilyen jellegủ intézményre.
} 
A bencésekkel közeli kapcsolatban állt báró Baich Mihály. Ez a filantróp, tehetős ember az eredetileg Festetics Andor által lakott szelestei kastélyban élt. A báró minden évben támogatott egy - a bencések által erre érdemesnek jelölt - ifjút, így 1918 táján Eiserth Pongrácot is. Mihály fia (aki keresztnevét a báró iránti tisztelet jeléül kapta) máig emlékszik a báróra és a csodálatos arborétumra, amely a kastélyt övezte. Endes lenyügöző botanikai ismeretei feltehetően nemcsak a kőszegi erdőkben tett barangolásokból, hanem az arborétumból is gyökereztethetőek. Szakembereket megszégyenítő rendszertani tudása volt a növényekről, erről laikus munkatársai sokszor meggyőződhettek, különösen a gyakori, általában kerékpáros intézeti kirándulásokon.

Ottlik Géza az „Iskola” egyik lapján írja a következőket: „Van egy nagyon mély lerakódás a létezésünk alján, a második vagy legfeljebb harmadik réteg lehet alulról számitva, ami már végleges és változhatatlan, ahol már nem mozdul az életünk, tehát rossz szó rá, hogy lelassit, hiszen egyáltalán mozdithatatlan és befejezett. Erös és szilárd tartalom ez az emberben, és nem valamilyen szomorú vagy halott dolog, söt bizonyos tekintetben éppen ez él igazán, ez az, amit létezésünk folyamán létrehoztunk, amit életre hivtunk életünk anyagából." Azt gondolom, hogy ez a nagyon mély „lerakódás” Felsőpulyán kezdődött és jelentősen vastagodott, rétegződött a határvidéken elhelyezkedő iskolában.

A kamaszok elképesztően kegyetlen világába bőséggel bepillanthat az olvasó és az asszociációk önként adódnak. Irodalmunk és nyelvünk balszerencséje, hogy a könyv máig nem kapta meg azt a nemzetközi elismerést, ami illetné. Ha Ottlik írt volna angolul és William Golding magyarul, akkor jó eséllyel nem a "Legyek ura” szerzo"je kapta volna a Nobel-díjat. Az „Iskola” is parabola, mint Golding legtöbb regénye. A „határ” számos szinten értelmezhetö, és Endes életében is többszörösen "határ-élmény" volt Köszeg, kitörölhetetlen nyomot hagyott benne. Meggyőződésem - bár ezt konkrétan soha nem erősítette meg -, hogy a többféleképpen definiálható „határ szituációnak" nagy szerepe volt abban, hogy később Nietzsche oly fontossá vált számára. Zarathustra mondja: ${ }^{10}$ "Köröket vonok magam köré és szent határokat; egyre kevesebben kapaszkodnak velem az egyre magasabb csúcsokra - hegységet épitek egyre szentebb hegyekböl." Az Egyetemi Életben (vide supra) megjelent interjúban azt mondta: „Sokat bolyongtam magányosan a hegyekben" - ez a mondat szinte alliterál a zarathustrai kijelentéssel. Nietzsche írja ${ }^{11}$ a Zarathustra keletkezésével kapcsolatban, hogy „minden döntö dolog'mégisből' keletkezik" - nem nehéz, különösen a későbbi események ismeretében, ráismerni a párhuzamokra. A 20. század első évtizedeiben az ökumené még csak kezdeti szakaszában járt, hiszen az 1920-as évekre esett az időszak, mikor - elsősorban a protestáns egyházak kezdeményezésére - világméretű mozgalmak, konferenciák szerveződtek a keresztény egység megvalósítása érdekében. Az ökumenikus mozgalom 1910-ben indult Edinburghból, kétséges, hogy ennek kedvező hatásai az 1920-as évek elejére elértek volna Kőszegre. A szigorú, szinte katonás rendet követő „Katholikus

${ }^{10}$ Friedrich Nietzsche, Így szólott Zarathustra. Régi és új táblákról (Budapest, 2016), 280.

${ }^{11}$ Uo., 485. 
Főgimnázium” egy evangélikus „bélyeget” hordozó fiatal fiú számára számos konfliktus forrása lehetett. Nem tudjuk, hogy a fiatal gimnazista Eiserth Pongrác mennyire ragaszkodott a keresztségben elnyert vallásához, de a nehéz gyermekkor jó alap lehetett a "mégis” mentalitás kialakulásához. Logikailag idekívánkozik az a megjegyzés, hogy a sok évtizeddel későbbi beszélgetéseinkben világossá vált, hogy Endes Pongrác formális módon nem gyakorolt semmilyen vallást. Soha nem próbálta meg, hogy az én hitem ellen érveljen, azt nagy tiszteletben tartotta. ${ }^{12}$

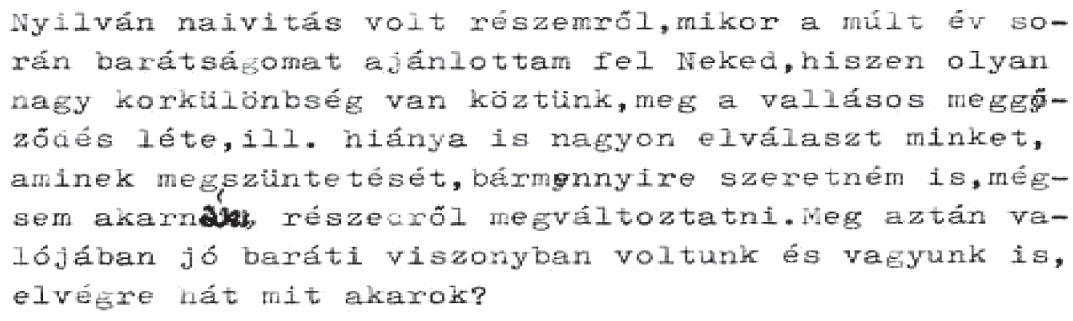

\section{Levélrészlet}

Expressis verbis soha nem tagadta Isten létezését. Beszélgetéseinkben sokkal gyakrabban idézte Nietzschét, mint a Szentírást, de az idézetek nem a vallás- és kereszténységgyülölő passzusokból származtak. Többször sarkallt a Zarathustra elolvasására, szerencsére nem várta, hogy mint ő, az eredeti nyelven olvassam. Endessel kapcsolatban nem az egyetlen rejtély, de a sorban előkelő helyen áll, hogy vajon miért tartotta ennyire fontosnak ezt a művet. Kétlem, hogy a mazdaizmus per se vonzotta volna, a ZendAveszta nietzschei értelmezése számomra sokszor áttekinthetetlen rendszert alkot, amiben Endes viszont valami különlegesen lebilincselöt talált. A „nagy visszatérés” nyomait sem találom életének egyetlen mozzanatában sem. Gombával sokat beszélgetett a Zarathustráról, a rejtélyt ő sem tudta megfejteni. Endes jól ismerte, idézte Szent Pál leveleit. Élete második felében az egzisztencializmus nagyon intenzíven foglalkoztatta. Abban az időben, amikor itthon még nehéz volt nyugati országokban kiadott könyvekhez hozzájutni, és én rendszeresen hosszabb időszakokat töltöttem Chicagóban, több mű megszerzését kérte tőlem. Ezek között az első William Barrett 1958-ban megjelent műve, az „Irrational Man: A Study in Existential Philosophy” volt. Néha az volt az érzésem, hogy bizonyos mértékig panteista szemmel értelmezte a létezést, egyértelműen csodálta a természetet, az élet bármilyen megnyilvánulásának analitikus tisztelete minden cselekedetét áthatotta, és ez különösképpen világosan tükröződött abban, ahogy a szövetek szerkezetének és müködésének egységét értelmezte. A képet színezi, hogy Nietzsche mellett G. K. Chesterton szintén kedvenc szerzője volt, csakúgy, mint

12 Számos levélrészlet abból az időszakból származik, amikor vendégprofesszorként rendszeresen hónapokat töltöttem Chicagóban. Endes professzor úr 1985-1992 között mintegy 50, sürủn gépelt levelet írt nekem mindennapjairól és saját magáról. 
Charles Lutwidge Dodgson (jobban ismert nevén Lewis Carroll), akik viszont istenhívők voltak. Thornton Wilder műve, a „Szent Lajos király hidja”, további adalék ehhez az összetett képhez. Endes intellektuális igényességére jellemző, hogy a felsorolt szerzők műveit eredeti nyelven olvasta és idézte.

Tudott, hogy a nyelvek iránti érdeklődése korán kezdődött. Nagymamája mellett anyanyelvi szinten megtanult németül, gimnáziumi évei során szilárd görög és latin nyelvtudásra tett szert, amit később angollal, sőt - gyermekeivel „versengve” - orosz ismeretekkel bővített. Utóbbinak jó hasznát vehette, szókincsét bővíthette életének abban a szakaszában, amikor Borisz Vasziljevics Petrovszkij professzorral dolgozott együtt.

Egyetemi tanulmányait a Budapesti Műszaki Egyetemen kezdte, a bölcsészettel is kacérkodott, de végül a Medicina győzött. Hallgatóként a Lenhossék Mihály által vezetett legendás hírü Anatomia ${ }^{13}$ Intézetben is tevékenykedett, de erről nincsenek részletes adataink. A kórbonctan iránti érdeklődése harmadéves korában kezdődött, amikor kapcsolatba került nemes Balogh Ernővel, aki a Pázmány Péter Tudományegyetemen a kórbonctan ny. r. tanára (1934-1945) és a Kísérleti Rákkutató Intézet vezetője (19341945), közben az egyetem rektora (1934-1935) volt. Externista (a mai „TDK-s” hallgatói státusznak megfelelő pozíció) tevékenységét sikeres szigorlata, illetve egy tanulmányi verseny I. helyezésének elnyerése után a kórbonctanon folytatta. Hamar kitűnt tehetségével és remek megfigyelőkészségével. Rohamosan gyarapodó tudása eredményeként egy alkalommal szakmai vitába keveredett az intézetvezetővel, és szerencsétlenségére neki volt igaza. Abban az időben is igaz volt a mondás: „The boss is not always right, but he is always the boss” - ráadásul ez a "boss” nagyon hiú ember volt! Nemes Balogh Ernő nagyon sajátos egyéniség kellett legyen, számos történet lelhető fel viselkedésével kapcsolatban. ${ }^{14}$ Tehetséges ember volt, Rockefeller-ösztöndíjjal az USA-ban is képezte magát. A II. világháború után állásvesztésre és nyugdíjmegvonásra ítélték (1945), de ennek az ügynek részleteit nem ismerem. Honti Józsefet idézve: „Ha valakire megharagudott, rögtön eltávolitotta az intézetböl. Igényes és munkakövetelö volt, de néha szeszélyes is. Az eltávolitottak voltak az ún. EKE (Eltávolitott Kórboncnokok Egyesülete). Egyik munkatársát például azért távolitotta el, mert a Bécsben tartott elöadására becsomagolt metszetek a kanadabalzsamtól összeragadtak. "Az tény, hogy elüldözte intézetéből azt a két embert, akikről bátran állíthatjuk, hogy a múlt század kórbonctanának két legszínesebb magyar képviselöi voltak: dr. Eiserth (Endes) Pongrácot és dr. Reichenbach (Romhányi) Györgyöt.

Kicsit visszaugorván az időben, néhány adalék az ifú Eiserth Pongrác életéhez. Bon vivant volt, a kemény egyetemi munka mellett maradt idő sportra, mulatásra (az utóbbit állítólag egyszer az EMKE kávéház egyik nagy tükre bánta, melybe pezsgősüveg repült valamely emelkedett hangulatú pillanatban). A bicikli korán elmaradhatatlan része

${ }^{13}$ Lenhossék Mihály több helyen síkra szállt amellett, hogy ez a helyes írásmód.

${ }^{14}$ Részletesen erről HonTi József, „A hazai kórbonctan a két világháború között a Magyar Pathologus Társaság mủködése tükrében” (A Magyar Orvostörténelmi Társaság és a Magyar Pathologusok Társasága plenáris ülésén, Budapesten, a Lukács fürdő klubhelyiségében 1983. május 26-án elhangzott előadás alapján), Orvostörténeti Közlemények 113-114 (1986): 129-142. 
lett életének, de rendszeresen járt úszni is. Nem sikerült kiderítenem, hogy pontosan mikor ismerkedett meg Rátai Györgyivel, aki diplomáját a Testnevelési Főiskolán szerezte. Remek, többszörös díjnyertes lovas volt, kiemelkedő eredményeket ért el lovaspólóban, később testnevelő tanárnőként dolgozott. Az tény, hogy a házassági ajánlat a Millenáris fürdő egyik medencéjében hangzott el: Eiserth Pongrác az egyik hossz leúszása után megvárta, hogy Rátai Györgyi beérje a medence végén, ekkor fordult hozzá: „Nem lenne a feleségem?” Rákoshegyen élt a Rátai család (2 lány, 3 fiú), az apa (Rátai János) Budapest székesföváros magas rangú alkalmazottjaként kapta a birtokot. Feltehető, hogy a család nem volt elragadtatva attól, hogy a szépséges leány egy apátlan, árva kórboncnokhoz kösse életét.

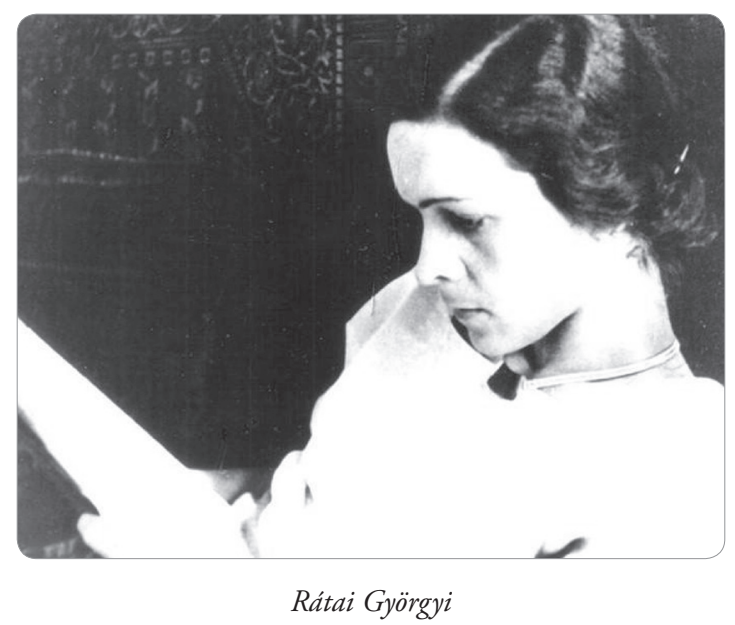

Nem is lett diadalmas lagzi, a sajátos leánykérést követően az Oktogon közvetlen szomszédságában lévő házasságkötő teremben (ma is ezt a funkciót tölti be) zajlott az esküvő úgy, hogy két járókelőt kértek tanúnak, akiket nem is ismertek. A szertartás végeztével a tanúkat a közeli talponállóban (jelenleg egy „TGIF” nevü ${ }^{15}$ szórakozóhely) egy-egy korsó sörrel vendégelték meg, majd ezt követően ment ki-ki a maga útjára. Érdekes, számunkra elképzelhetetlen, hogy az ifjú patológusnak külön engedélyt kellett kérnie, hogy megházasodjon. A házas lét ugyanis „elvonja a fiatal munkaerö energiáit a munkától”, ezért a családalapításnak előfeltétele volt az intézetvezetői engedély. Eiserth Pongrác 1931-ben kezdett dolgozni, viszonylag hamar engedélyt kapott a nősüléshez. ${ }^{16}$

A mellékelt montázsképen szereplő Simon András-rajz nem túlzás: kettőjük kapcsolata tényleg ilyen volt. Endes Mihály elmondása szerint édesanyja „mélységes kút” volt, aki mindent elnyelt, ami a harmóniát esetleg zavarhatta volna. A házasságkötést

15 TGIF: Thank God It’s Friday = Hála Isten, péntek van. Amerikai étteremlánc.

16 Számos évszámban bizonytalan vagyok. Endes Mihály szerint a házasságkötés 1932-ben volt, Gomba Szabolcs írásában 1936 szerepel. Bármennyire is igyekeztem, írott dokumentumok hiányában sok esetben nem sikerült biztos adatra lelnem. 
követő évek szép, de nehéz időszakot jelentettek: Mihály 1938-ban, György 1940ben, János 1942-ben született. A gyermekek születésekor a család a Horánszky utcában lakott, Tornyai János festőművész is élvezhette az Endes fiúk „élénk” társaságát. Az kérdés marad, hogy a fiúk csintalanságainak tényleg szerepe volt-e abban, hogy a család viszonylag sokszor költözött, bár Mihály nem vetette el ennek lehetőségét. A gyerekekről (ugyancsak az Egyetemi Életben) ezt mondta: „Nekem sajnos a saját gyerekeim nevelésére kevés idöm jutott. Így azután nem a szelíd meggyözés volt a módszerem, hanem a szigor. Néha bántott, hogy a kemény kéz politikáját folytatom, de most utólag úgy érzem, hogy talán nem tettem rosszat. Tisztességes emberek lettek a fiaim. Egyikük gyermekorvos, másikuk állatorvos, a harmadik röntgenorvos."
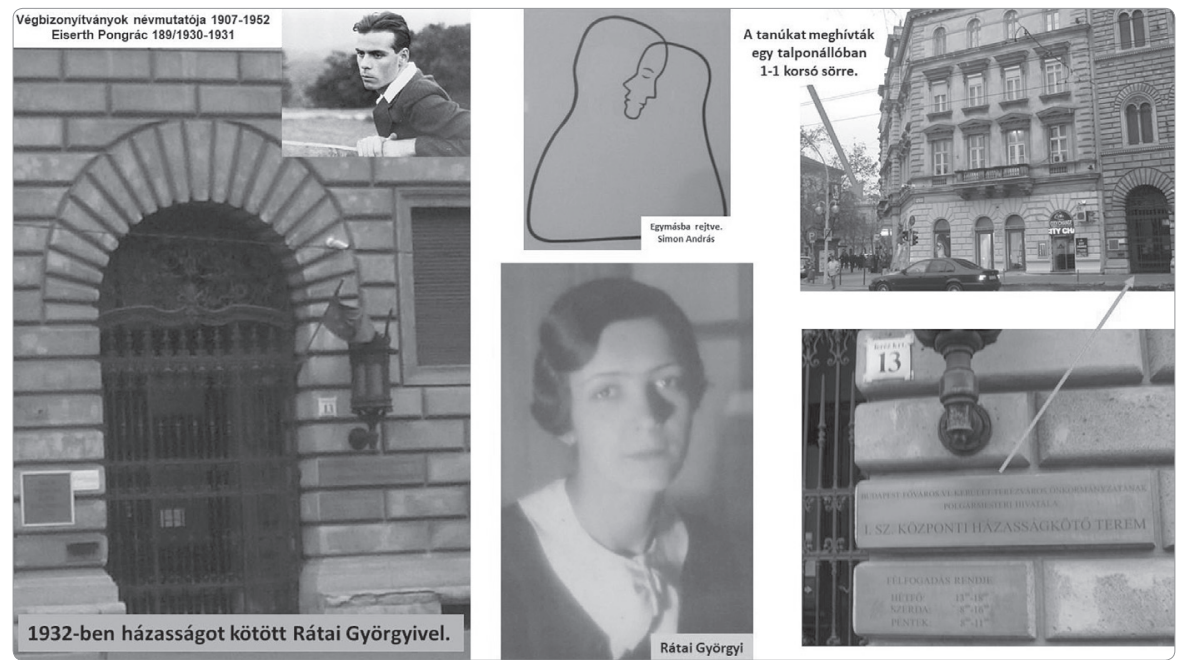

A biciklizés állandó része volt a napi programnak, de Mihály születésekor motorral érkezett, s egy kisebb karambol után a kórházban némi bizonytalanság keletkezett: ki szorul nagyobb segítségre, a fáradt, de boldog édesanya vagy a traumatizált ifjú atya?

Miután az intézetből távozni kényszerült, elképesztő munkabírással számos budapesti egészségügyi intézményben dolgozott, gyakorta egy időben több helyen. Felesége (akit „Gyuri”-nak becézett), a gyermekek lefektetését követően késő éjszakába nyúlóan gépelte a kórszövettani leleteket - ez később Debrecenben is így volt, még magánlevelezését is felesége gépelte. 

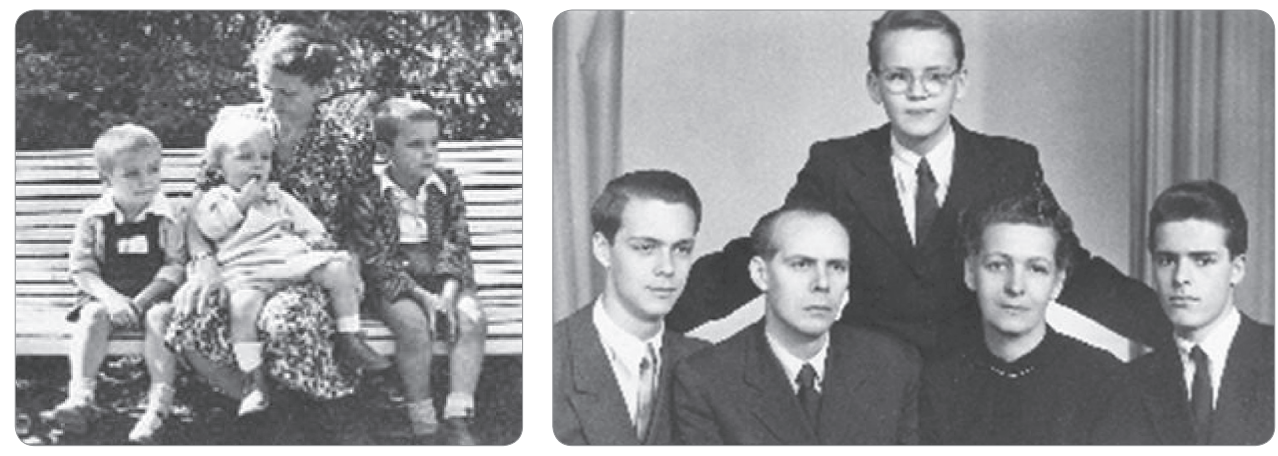

Felvételek az Eiserth, majd Endes családról

Munkahelyei a székesfóváros orvostörténeti szempontból kiemelkedő jelentőségű kórházai voltak. Ebben az időszakban az egyetemi intézmények és a nagyobb kórházak viszonya elég szövevényes volt, nemritkán a kórházakban folyó rutin egészségügyi munkát egyetemi állást is betöltő szakemberek végezték. A város polgári kórházai még a 18. század elejének nagy pestisjárványai közepette épültek. Budapest a kiegyezés után egyre nagyobb hangsúlyt fektetett modern kórházak létrehozására. Ezek közül az első az 1885. augusztus 5-én megnyílt Üllői úti Új Kórház volt, amely 1894-ben vette fel a Szent István nevet. Végzése után 2 évig (1932-1933) gyakornokként itt, illetve a Fehér Kereszt Gyermekkórházban dolgozott. Utóbbiból fejlődött ki a SOTE II. Sz. Gyermekklinikája (Tüzoltó utca). A Szt. Rókus Kórház Kórbonctani Intézetében segédorvos, alorvos, majd klinikai adjunktus beosztásban dolgozott (1933-1945), egyúttal a pécsi Erzsébet Tudományegyetem Kórbonctani Intézet egyetemi tanársegéde (1933-1945), majd magántanára (1945) volt. A Rókus Kórház egyike Európa és egyben Budapest legrégebbi közkórházainak. Főbejárata felett ma is olvasható eredeti funkciójának definíciója: „Pestanum Calamitosorum Domicilium” - „Pesti Polgári köz Ispotály” volt az első neve. 1847-ben itt történt az első éteres-kloroformos altatás (Flór Ferenc). 1898-ban Donáth Gyula vezetésével itt kezdte el működését Európa első orvosi röntgenlaboratóriuma.

A Rókusban Czeyda Pommersheim Ferenc (ő operálta Rátai Györgyi pajzsmirigyét, a mütét dacára később a hyperthyreosis sok gondot okozott Endes feleségének), Hüttl Tivadar, Kubányi Endre professzorok vezették a sebészetet. Eiserth Pongrác „végleges alorvos” beosztásban Wolff Károly főorvos mellett látta el a prosectori munkát. Elődei között szerepel Semmelweis Ignác (aki ugyan nem fóállásban, de végzett boncolásokat), Krompecher Ödön (a basalioma mint önálló entitás leírója) és Scheuthauer Gusztáv, ugyancsak neves kórboncnok, Rokitansky-tanítvány. A folyamatosan bővülő ágyszám (már 1862-ben 682 ágy volt a kórházban) és szélesedő profil rengeteg feladatot jelentett a kórboncnokoknak. Ez magyarázza, hogy Eiserth Pongrác számos munkahelyén egyedülállóan gazdag tapasztalatokra tett szert, és lassan országosan ismert kórszövettani diagnoszta lett. Egyre-másra tudományos közleményei is megjelentek. 
Gomba Szabolcs írásában szerepel, hogy Eiserth Pongrác egy rövid időre kapcsolatba került a nemzetiszocialista mozgalmak valamelyikével. Ebben szerepe lehetett nemes Balogh Ernő és Wolff Károly hatásának, de ez is csak feltételezés. Erről tőle soha nem hallottam, és az igazság megkövetelné a „másik fél” véleményének ismeretét is. A Wikipédia szócikke is ezt támasztja alá: „Az 1930-as években a legtöbb nemzetiszocialista pártot a sürü betiltások és újjáalakulások, valamint összeolvadások és kiválások, illetve a programjaik hasonlósága miatt az elnevezésüktöl és a személyi különbségektöl függetlenül gyakorta egyszerüen Magyar Nemzeti Szocialista Párt (a nemzetiszocialistát hol egybe, hol külön írva) néven emlitették; ezek utólagos megkülönböztetése egymástól mára gyakorlatilag már alig vagy egyáltalán nem lehetséges."

A háború után a Mosonyi utcai fogházba került, a Budapesti Népbíróság minden vád alól tisztázta. Ennek az időszaknak az egészségügyi helyzetéről (beleértve a politikai zűrzavart is) jó képet ad a Petőfi Kör 1956. október 23-án „A fiatal orvos és társadalom” címmel folytatott vitájának jegyzőkönyve, de ennek a máig sok szempontból tisztázatlan periódusnak tárgyalása messze túlmutat írásom célkitűzésein. Legyen elég a jegyzőkönyvből egy részletet idézni: „Molnár György: 1945-ben a Rókus Kórházban, mint segédorvos dolgoztam. Ekkor történt, hogy a szakszervezet segitségével ott vezetö szerephez jutott Wolff Károly kebelbarátnóje és volt titkárnöje: Zalka Ödönné, ${ }^{17}$ aki müködését azzal kezdte, és hasonlóképpen folytatta, hogy két mütét között levezényelte a kórház orvosait a konyhába zöldborsót pucolni." 18 Az ebben a légkörben történt feljelentések és döntések reális megítélését semmiképpen nem vállalhatom.

A II. világháború sok megpróbáltatással járt a család számára. Az öt testvér közül Györgyi vette magukhoz édesanyját, így öt emberért dolgozott, majd aggódott és szó szerint küzdött Eiserth Pongrác. A nagymama nem volt hajlandó lemenni az óvóhelyre, így a vő járt fel két légiriadó között, hogy gondját viselje. Házuk bombatalálatot kapott, élelmük alig volt. Ha a fellopózást kiegészíto „portya” sikeres volt, néha sikerült fagyott lóhúshoz jutni. A „mintavételhez” egy ebonitnyelü (másra nem használt!) szervkést ${ }^{19}$ vitt magával (Endes Mihály emlékszik a nevezetes eszközre). Györgyi vidékre járt, időnként vonatok tetején utazott. Lovaglással nyert érmeit és kupáit cserélte krumplira, sajtra és más élelmiszerre. A helyzet lassan rendeződött, és Endes a Koltói Anna Baleseti Kórház, illetve a Klinikák Kórbonctani és Kórszövettani Részlegének vezető föorvosa (1947-1953) lett. A névváltoztatásra 1948-ban került sor, elsősorban azért, mert az Eiserth név helyes kiejtése és írása sokaknak gondot jelentett. Ez különösen bosszanthatta, hiszen köztudottan érzékeny volt bármilyen íráshibára, ezt később, mi-

${ }_{17}$ Zalka Ödön jó szakember [kórboncnok], de gyenge akaratú ember volt, „társutas kommunista”. NÉMETH György, Hogyan irányitotta kórházait a föváros a dualizmus korától a második világháború végéig? Magyar Nemzet, 2008. április 8.

18 Petöfi Kör 2016. A Blinken OSA Archivum, az ELTE Társadalomtudományi Kar és a Göncz Árpád Alapítvány közös, hat részből álló vitasorozata.

${ }^{19}$ Kórboncoláskor az egyes szervek vizsgálatához hozzátartozik a széles metszlapok készítése, ehhez szükséges eszköz a szervkés. 
kor a tankönyv kefelenyomatainak javítását rám bízta, magam is sokszor tapasztaltam. „E” betűs nevet kellett találni, mert az „EP” monogram minden ingében benne volt. Három „E”-vel kezdődo nevet tárt a családi tanács elé („Nem mintha lett volna valódi beleszólásunk", emlékszik erre Mihály és János), a másik kettő mára már nem ismert.

A Koltói-Kórházban Hedri Endre professzor vezetésével alakult újjá a budapesti III. Sz. Sebészeti Klinika, melynek pathologus tudományos munkatársaként 1949-1953 között tevékenykedett. A III. Sz. Sebészeti Klinika vezetésére 1949-ben meghívták Borisz Vasziljevics Petrovszkij szovjet sebészprofesszort, aki új típusú sebészi iskolát alapított. Petrovszkij később a brezsnyevi Szovjetunió egészségügyi minisztere lett, ő végezte a Szovjetunió első veseátültetését, rendes tagja volt a Magyar Tudományos Akadémiának. Nagy tapasztalatokkal rendelkező sebész volt, számos kiváló, vezető magyar sebész nála kezdte pályafutását, de azt is meg kell említeni, hogy ő pedig magyar sebészektől tanult sokat a nyelőcső betegségeinek műtéti kezeléséről. Petrovszkij nagyon meg volt elégedve Endes Pongrác munkájával. Kettejük kapcsolatához füződik az a legenda, hogy Petrovszkij operálta Endes gyomortumorát (mások szerint Pommersheim végezte a műtétet). Állítólag a beteg kezébe követelte a műtéti resecatumot, mondván: „Ennek a szövettanát ÉN fogom megnézni.” Nehéz elképzelni, hogy mindez technikailag hogy zajlott, a lényeg, hogy a daganat jóindulatú (neurilemmoma) volt. Endes Debrecenbe kerülése előtt a III. Sz. Belgyógyászati Klinika Patológiai Osztályának osztályvezető egyetemi docense (1953-1954) volt.

A Koltói-időszakban két fontos tudományos eredménye született. Alapvetően új megfigyelésekre jutott a jóindulatú prosztatamegnagyobbodás kialakulásának folyamatáról. Felismerte és elsőként közölte, ${ }^{20}$ hogy a mirigy kötőszövetes elemeinek (angio-leiomyomatosus) burjánzása indítja el a folyamatot, amit másodlagosan követ a mirigyek kóros növekedése. A felismerést nagyban segítette annak a szövettani festési eljárásnak a kidolgozása, ami éppen a mesenchymalis sejtek és rostok speciális elkülönítését teszi lehetővé (Endes-féle trichrom festés, az azán és a Mallory által kidolgozott foszforwolframsavas haematoxilin eljárások kombinációja). Ennek a hisztotechnikai módszernek a későbbi munkáiban is nagy jelentősége lett.

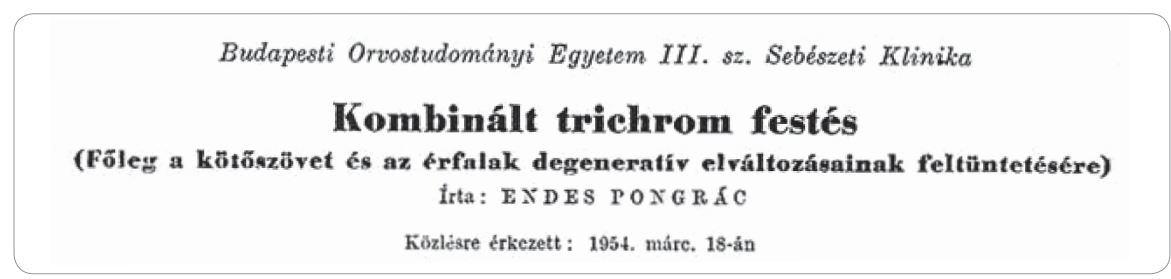

Mindeközben Pécsett, Entz Béla professzor mellett végzett tudományos kutatómunkát, aminek eredményeként 1945-ben egyetemi magántanári címet szerzett. 1951-ben

${ }^{20}$ Sajnos a kor szokásainak megfelelően magyarul, illetve németül, így a mai angolszász dominanciájú orvosi szakirodalomban ez a szerzői „prioritás” gyakorlatilag ismeretlen. 
a Petrovszkij professzorral végzett közös munkát a Népjóléti Minisztérium elismerő oklevéllel honorálta. 1952-ben, pécsi tudományos tevékenysége alapján a TMB megítélte számára a kandidátusi tudományos fokozatot. ${ }^{21}$ 1953-ban egyetemi docenssé nevezték ki.

Nehezen szánta rá magát, hogy vállalja a debreceni intézet vezetését, noha az Egészségügyi Minisztérium többször is határozottan felszólította. Felesége nagyon ellenezte a költözést, szerette a pesti társaságát, akikhez Debrecenből is sokáig visszajárt. Debreceni kinevezését erősen szorgalmazta Petrányi professzor, akinek szüksége volt egy vesepathologiában járatos szakemberre. Endes vesepathologia iránti érdeklődése Gömöri Pál professzorral folytatott kollaborációjának idejére datálható. Végül 1954. november 1-én nevezték ki a DOTE Kórbonctani Intézete tanszékvezetőjévé, illetve klinikaigazgató egyetemi tanárává.

Debrecenben közvetlen elődje Kellner Béla volt, az intézet korábbi vezetői között számos neves szakembert találunk (a teljesség igénye nélkül: Ökrös Sándor, Sántha Kálmán, Orsós Ferenc). Kellner Béla távozása után dr. Nagy András adjunktus kapott megbízást az intézet vezetésére, ő fogadta Endest, kettejük között igaz barátság alakult $\mathrm{ki}^{22}$ Endesnek kevés tapasztalata volt az egyetemi oktatásban, nagyon sokat segített neki Nagy András, akinek előadásait az első évben Endes rendszeresen meghallgatta. Saját bevallása szerint tantermi előadásai előtt kifejezetten izgult (ezt nem lehetett észrevenni), előadásai hallatlanul precízek, de számomra szárazak voltak. Ezzel gyökeres ellentétben, az V. éven tartott klinikopathologiai előadásai felejthetetlenek, csakúgy, mint „az óravégi 5 percek”, amikor kultúrtörténeti fejtegetésekkel nevelte a hallgatókat. Az 1954-es intézeti tablón szereplő munkatársak (B. Soltész Margit, Czenkár Béla, Dévényi István, Győry György, Gomba Szabolcs, Haraszti Antal, Kelemen János Tibor, Keresztury Sándor, Királyfalvi Elek, Megyeri László, Nagy András, Simárszky János, Slowik Felícia, Stipula Magda) segítségével kezdte saját elképzelései megvalósítását.

Az intézethez füződő viszonyát alapvetően meghatározta, hogy 1978-ig nemcsak munkahelye, hanem lakása is az épületben volt. Kevesen vagyunk már, akik emlékszünk az I-es, II-es és III-as számú dolgozókra. Délután fél egykor visszavonult ebédelni, amit szieszta követett. A fél háromig terjedő időben csak egy indokkal lehetett zavarni, ha intraoperatív konzultáció ("fagyasztott metszet” értékelése) kapcsán nem tudtunk kielégítő választ adni a sebésznek. Ilyenkor hálósapkában, köntösben ült a mikroszkóp mellé. Munkába állásomat követően viszonylag hamar és elég gyakran hárult rám a lakás őrzésének feladata, miután ebben az időben szüleimmel az I-es sz. tanári villában laktam. „Neked mindegy, hogy hol alszol”- mondta, de a papagájt (Györgyi néni kedvence volt) etetni kellett (a lakásra valójában teljesen felesleges volt „vigyázni”). Egy ilyen

${ }^{21}$ A szovjet rendszerből átvett, etimológiailag nehezen értelmezhető cím. A szó eredeti jelentése „fehér”, történetileg utalhat a fehér színű tógát viselőkre, akik valamilyen pozíció elnyerésére aspiráltak. Szerencsére mára eltűnt ez a korábban a Tudományos Minősítő Bizottság (TMB) által odaítélt cím, korábban viszont alapfeltétele volt az egyetemi hierarchiában való előbbre jutásnak.

22 Endes, betegágyából felkelvén, taxival meglátogatta dr. Nagy Andrást a halála előtti estén. Tudomásom szerint ő volt az utolsó ember, akivel Endes beszélt. A beszélgetés részletei nem ismertek. 
alkalommal a madár elpusztult, és a Prof. zordsága csak akkor enyhült, mikor a boncolás tisztázta, hogy a halál oka nem éhezés volt.

Magával és munkatársaival szemben rendkívül magas szakmai követelményeket támasztott. Ez a bonctermi tevékenységre ugyanúgy vonatkozott, mint a biopsziás diagnosztikus munkára és az oktatásra. Az akkori intézeti légkör a mai világban már elképzelhetetlen. A magas színvonal biztosítása érdekében könyörtelen volt. Ez a kifejezés riasztó, de a korszak kiemelkedő teljesítményt nyújtó orvos egyéniségei (pl. Baló, Romhányi, Környey, Szentágothai) nem tolerálták a felületes, gondatlansággal „szennyezett” szemléletet, ahogy saját apám mondta: „a szakmai trágárságot”. Én Endes kinevezését követően 21 évvel kezdtem az intézetben dolgozni, de ez a szellem akkor is töretlen volt. Egy alkalommal (a konkrét okra és szituációra már nem emlékszem), nem tudván, hogy az „Öreg” mögöttem áll, kifakadtam: „Micsoda kupleráj!” - máig hallom jellegzetes hanghordozását: „Kolléga úr, jegyezze meg, a kuplerájban rend van, ha nincs rend, nincs üzlet!" Munkatársait csak sikeres szakvizsga után tegezte, ami mindvégig egyoldalú maradt (a „csendörpertu”23 mára lassan kivesző történelmi fogalom). Vizsgán a saját fiait is magázta. Mikor Jánost megbuktatta, ezt így adta tudtára: „Kolléga úr! Ma nagy szomorúságot okozott az édesanyjának."

A pathologus munkája mindenekelőtt „mintázatok” összehasonlítható felismerésén alapszik: ehhez elképesztő érzéke volt, így minden szabálytalanságot észrevett, semmiféle rendetlenség nem kerülte el a figyelmét. Ez egyaránt vonatkozott a „rendetlen” gondolkozásra, a pongyola írásmódra, a fegyelmezetlen beszédstílusra, de az intézet bármely sarkában felfedezhető gondatlanságra is. A boncterem „ragyogott”, a laboratóriumokban elképzelhetetlen volt bármilyen hanyagság, a kísérleti állatistállónak ugyanúgy rendben kellett lennie, mint a könyvtárnak ( $O$ tempora, o mores!). ${ }^{24}$

A „Mortui vivos docent” ${ }^{25}$ elvet maximálisan figyelembe véve a medikusok és szakorvosok képzésében is nagy hangsúlyt fektetett a boncolások eredményének szigorú, klinikai-pathologiai értékelésére. A halottak méltóságának megőrzését kiemelten fontosnak tartotta, és ehhez hozzátartozott az is, hogy nem türt igénytelenséget abban, hogy a boncolás technikailag kifogástalan legyen, hiszen csak így vált lehetségessé a kóros elváltozások értelmezése. Mindennap 10 órakor saját maga vezette az „Epikrizist” - ilyenkor az előző napon, a klinikák bármelyikén elhunytak boncleletének értelmezésében az összes megjelent klinikus aktívan részt vett. Ezek a megbeszélések a részt

${ }^{23}$ A „pertu” latin eredetű kifejezés a tegező viszony érzékeltetésére: per (révén) + tu (te). A csendőrök jobbára tegező formában szólítottak, de hatalmi pozíciójuk többnyire nem tette lehetővé, hogy őket is tegezzék.

${ }^{24}$ Cicero Catilina elleni első beszéde. A teljes mondat: O tempora, o mores! Senatus haec intellegit, consul videt, hic tamen vivit! (Ó idők, ó erkölcsök! A szenátus tudja, a konzul látja mindezt!)

${ }^{25}$ "A holtak tanitják az élöket” - sokáig az intézeti boncterem bejárata felett is olvasható volt ez a kórboncolást magyarázó felirat, aminek vitathatatlan igazsága háttérbe szorult, ami sajnálatosan mára nemcsak a bonctermek feliratának eltűnésében érhető tetten, hanem a kórboncolások számának (és gyakorta színvonaluk) csökkenésében is. 
vevők számára állandó és nagyon magas színvonalú oktatást, más módon meg nem szerezhető továbbképzést jelentettek. Az elhunyt korábbi kezelőorvosa és munkatársai a klinikát vezető professzor vezetésével jelentek meg, akik aktívan részt vettek az esetek megbeszélésében. (Ma az epikrízis legtöbbször elmarad, ha néha látunk klinikust, az legtöbbször az adott osztályon dolgozó legfiatalabb kolléga. Máig tapasztalom, hogy minden egyes boncolás feltárhat korábban nem látott abnormitásokat.) Endes idejében a szabad szemmel szokatlannak tünő elváltozásokból mindig részletes szövettani feldolgozás készült, és csak olyan kolléga kerülhetett kapcsolatba élőből eltávolított anyagokkal (biopsia), aki legalább három éven át a bonctermi (autopsia) anyagok vizsgálatával képezte magát. Szakvizsga előtt az orvosoknak hosszabb ideig saját maguknak kellett a bonctermi anyagaikat szövetileg feldolgozni, beleértve a beágyazást, metszést és festést is. Nem tudom, hogy kinevezését követően mennyi idővel vált általánossá, hogy az orvosok egymás között gyakorta cseréltek metszeteket, a kérdés mindig ugyanaz volt: „Alapszövet? Elváltozás?” - ez számomra az egyik legösztönzőbb, spontán oktatási forma volt. A humor nem hiányzott a napi életből, időnként előfordult, hogy valaki a Közértben ${ }^{26}$ vásárolt szafaládéból készült metszetet kapott, lehetőleg valamilyen bonyolult szövetfestési eljárással feldolgozva. Évente számos alkalommal Endes az egész klinikatelep számára konferenciákat rendezett, ${ }^{27}$ melyek didaktikai értéke felbecsülhetetlen volt. Mindehhez szükség volt arra a lenyügöző tapasztalatra, amit korábbi pályafutása során gyüjtött.

Az intézeti élet napi problémáit a 3/410-kor, teázással egybekötött megbeszéléseken volt lehetőségünk megbeszélni. A hétfő délutánonként zajló „referálókon” a Prof. által kijelölt angol, német, orosz és magyar nyelvű folyóiratcikkek szakmai megbeszélése zajlott. Érdekes módon francia nyelvű folyóirat nem járt az intézetbe. Az 1970-es évek közepén, mikor világossá vált, hogy a pathologia nemzetközi nyelve is az angol lett, a referálókon egy-egy beszámoló ezen a nyelven hangzott el, és a vitát is angolul kellett folytatni.

Zárkózottsága, megközelíthetetlensége, ridegnek tűnő szigora közmondásos volt és medikus élményeim ezt sokban alátámasztották, de későbbi kapcsolatunk során világossá vált, hogy ez sokban álca volt. Egy alkalommal átgázoltam az intézet előtti füves területen (nem láttam, hogy éppen arra érkezik), ami főbenjáró bün volt. Megkérdezte: „Mondja, Kolléga úr, legelni is fog?” Az Ottlik által említett rétegek mélyére valószínűleg csak „Gyurit” engedte látni. A barátsággal kapcsolatban többször idézte nekem Zarathustrát, aki nagyon elítélően szól arról a típusú barátságról, melyben valaki „magát feltáró, leleplezö, kiadó" viszonyt alakít ki másokkal. A Debrecenbe érkezése elötti időkből sokszor emlegette Szinay Gyula, Romhányi György és Ringelhann Béla profeszszorokhoz füződő kapcsolatát. Debreceni tanártársai közül kétségtelenül baráti viszony füzte Pongor Ferenchez (tüdőgyógyász-professzor), jó kapcsolatot ápolt Ádler Péterrel (sztomatológus, fogorvos), Hullay Józseffel (idegsebész), később Rák Kálmánnal (bel-

\footnotetext{
${ }^{26}$ A szocializmussal együtt ez a kiskereskedelmi áruda is kiveszett életünkből.

${ }^{27}$ A legendás hírű „KPK”-k (kliniko-pathologiai konferenciák) mára szintén eltűntek a régmúlt ködében.
} 
gyógyász) és Módis Lászlóval (aki „mert” engedelmeskedni a pertu felszólításnak, és valódi tegező viszonyba került vele. Gomba Szabolcs, saját bevallása szerint, nem „tudta” ezt megtenni). A debreceni professzorok tarokkos, bohém körének nem vált tagjává, bár néhány focimérkőzésen aktív szereplő volt. A futball (csakúgy, mint a biciklizés) elválaszthatatlan része volt életének. Tudott volt, hogy metszettel bármikor be lehetett hozzá kopogni, de az esti konzultációk kérésekor figyelembe kellett venni, nincs-e éppen „fontos” meccsközvetítés a televízióban. Az alábbi dokumentum ${ }^{28}$ nemcsak ebből a szempontból tanulságos, de személyiségének több vonásáról is árulkodik.

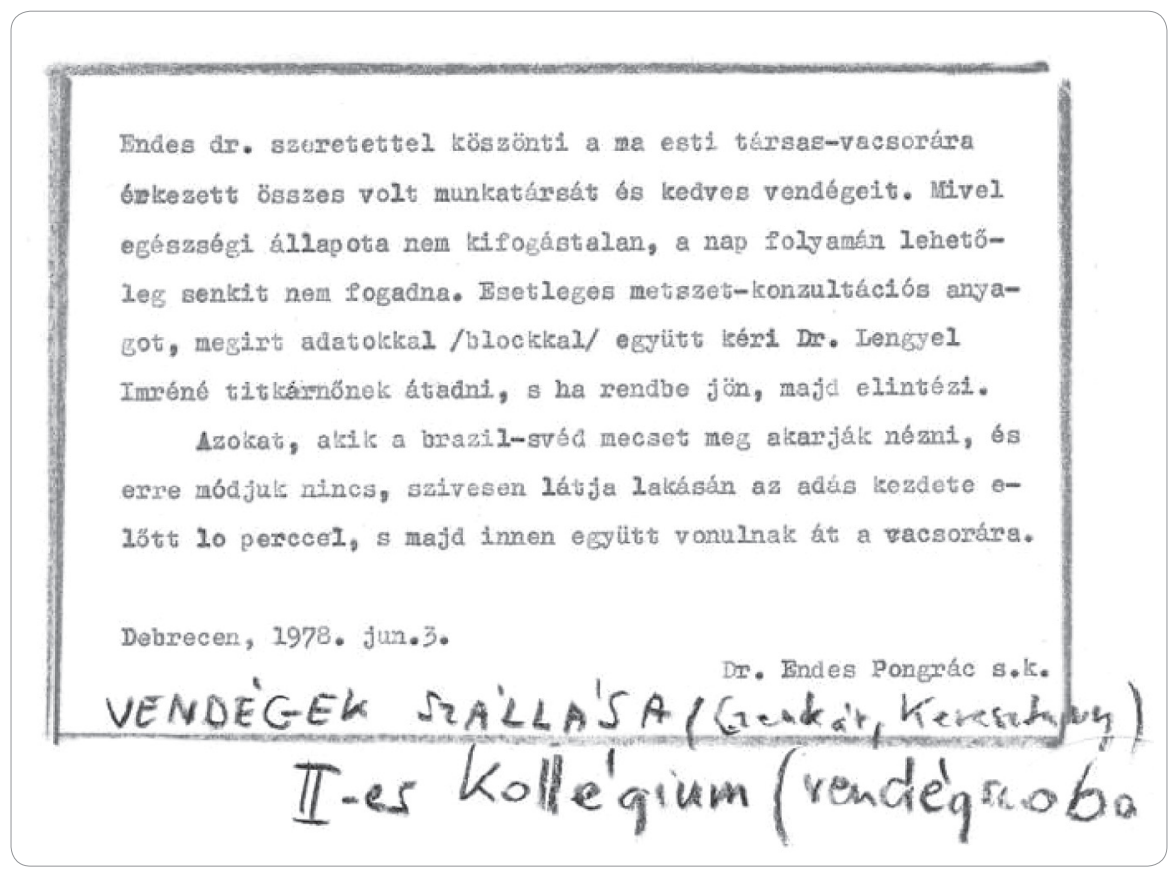

Sajátos, de jellemző szokása volt, hogy munkatársaival gyakorta cédulák segítségével érintkezett. Krasznai Géza föorvos úr emlékezik rá, hogy a korai időszakban gyakorta előfordult, hogy este 6 óra körül a titkárnő szétosztotta az aktuális feladatokat felsoroló cédulákat. Én is sok ilyen cédulát kaptam és szerencsére sokat meg is őriztem. Nagyon sokszor latinul írt, de nem volt ritka, hogy egy-egy cédulán (vagy később, mikor kapcsolatunk bensőségessé vált, levelezőlapokon) latin, görög, angol és német mondatok keveredtek. Természetesnek vette, hogy számomra ez nem jelent gondot (nem így volt). Fordítást csak a Nietzsche- és Rilke-idézetekhez mellékelt. Természetesen az idézeteket a pillanat diktálta igénynek megfelelően fejből, de mindig abszolút pontosan vetette papírra. Kézírásának folyamatos romlása nagyon elkeserítette, az utolsó cédulák néha alig voltak olvashatóak.

${ }^{28}$ Ez a cédula az 1978-ban, Debrecenben rendezett Magyar Pathologus Társaság tudományos ülésének idejéből származik. 


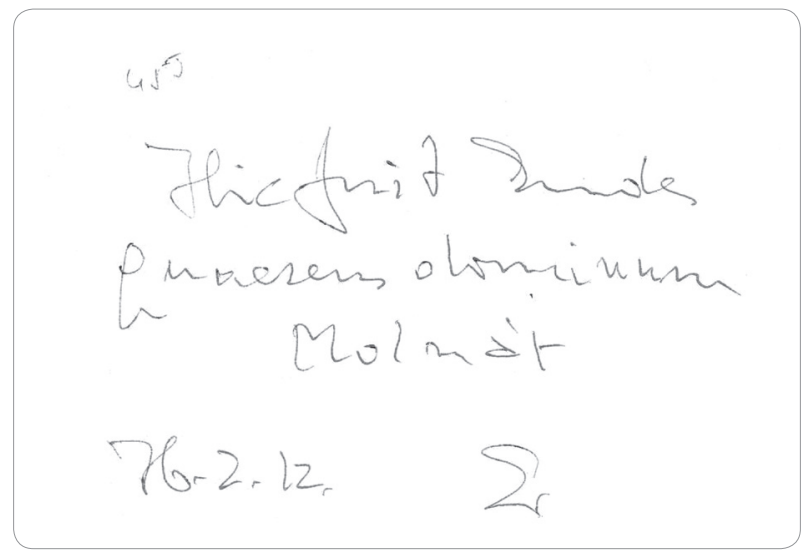

„Hic fuit Endes querens dominum Molnár"

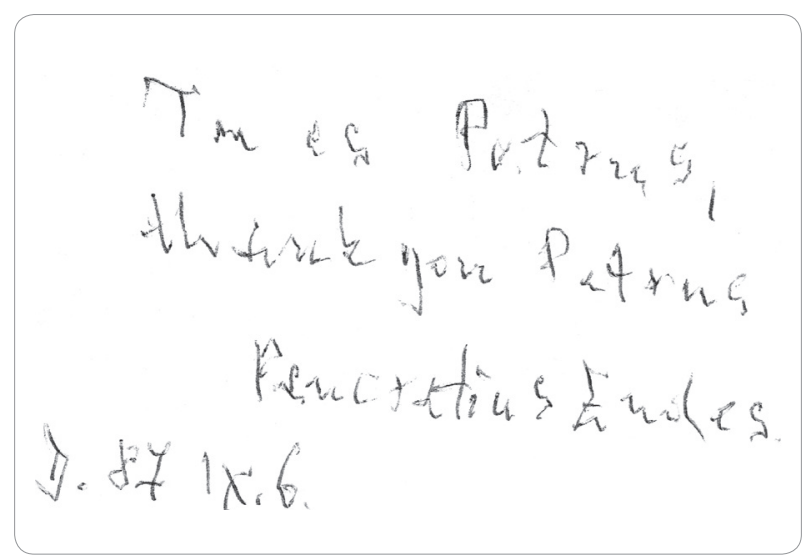

"Tu es Petrus, thank you Petrus. Pancratius Endes"

Gomba Szabolcs írása részletezi az intézeti tudományos tevékenységet (közli az általa feltalált, de beismerten hiányos publikációs listát is). Az MTA „Nagydoktori” fokozatát a vese juxtaglomerularis apparátusának müködését tisztázó vizsgálatainak eredményei alapján kapta. Nehezen szánta rá magát, hogy közleményt írjon, lelke mélyén sokkal jobban izgatta egy metszet megfejtése, mint a tudományos hírnév.

Felejthetetlen emlék marad annak aurája (ami egyben auraria fodina ${ }^{29}$ is volt), ahogy mikroszkóphoz ült. A digitalizálódó világ számára nehéz megfogalmazni azt az érzést, ami akkor fogja el az embert, ha az okuláron keresztül feltáruló rejtélyekre rácsodálkozik. Máig bámulatos számomra, hogyan volt képes heteken keresztül ugyanazokat

${ }^{29}$ Auraria fodina: aranybánya. 
a metszeteket nézni, mentálisan ízekre szedni, majd újra összerakni a festett mintázatokat addig, míg a rendezetlenségből (hiszen minden kóros állapot a normális, sui generis rend felbomlásához vezet) deduktív, de analógiás gondolkodás útján kórismét (milyen mély értelmű a magyar kifejezés és mennyire hűen visszaadja a „dia” + „gnosis” jelentést) felállítani. Az analógiás (képet hasonlítok képhez) gondolkodás az orvosi látásmód alapja, de különösen tetten érhető a morphologiai diagnosztikában. ${ }^{30}$ Endes fejében felmérhetetlen képanyag tárolódott, ehhez hasonlította az okulárokon keresztül feltáruló látványt, felismerte a különbségeket és hasonlóságokat, és ezek elemzése vezette a helyes véleményre, amit abban az időben sokszor, az egész országban, csak ő volt képes megfogalmazni. Az édesapám szájpadjáról eltávolított növedék metszetébe nézve megnyugtatott: „Nem malignus!” Friss szakvizsgámra szerzett ismereteim birtokában soroltam a számomra ominosus jeleket és megkérdeztem: „De miért nem?”- „Mert nem úgy néz ki!”- volt a válasz.

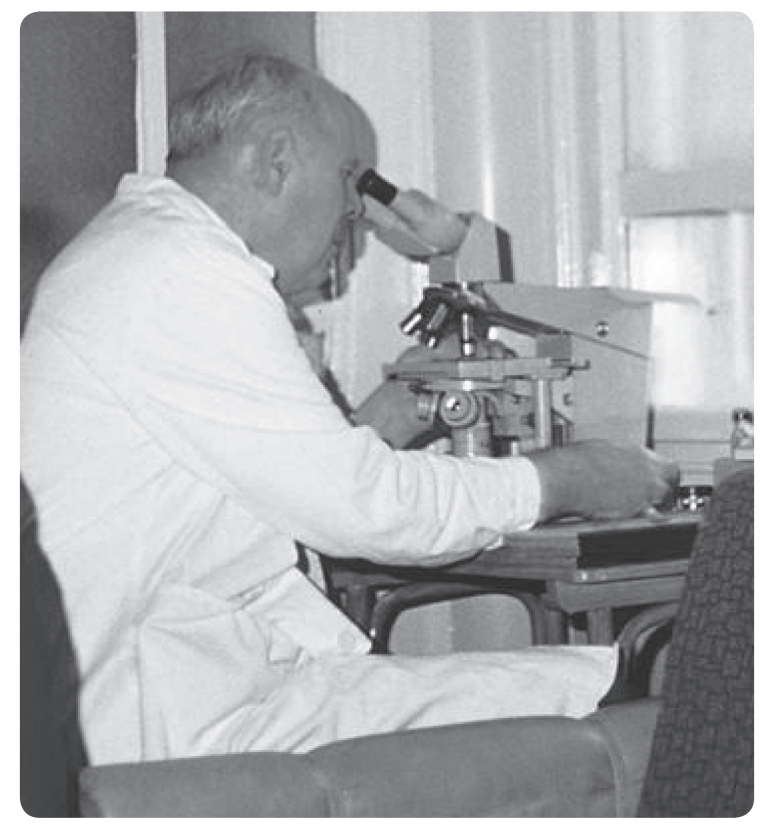

„No vajon mi is lehet ez?” Sajnos olyan képem nincs, amelyen saját, fekete, Zeiss mikroszkópjába néz

A mikroszkopizálás számára esztétikai örömet okozott. Erről egyik USA-ba küldött levelében írt:

${ }^{30}$ A „képek” értékelése mindennapi szellemi működésünknek is elengedhetetlen része. Ezzel kapcsolatban nagyon sok meglepő információ található Ronnberg és Martin munkájában. Ami RonNBerg és Kathleen Martin, The book of symbols. Reflections on archetypal images (TASCHEN GmbH, 2010). 


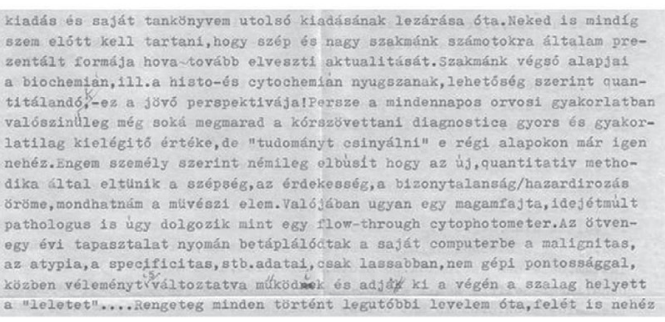

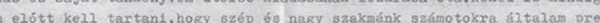
a trit lormaja hova-tovab elveszti aktualitasat.szakaank végsó alapjal Wrochemlan, 11l.a histo-és cy tochemlan nyugszanak, leketórég szerint quan-

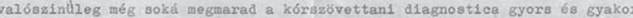
latilag klelébitob értéke, de "tudiományt cainyálnin" e régi alapokon már isen

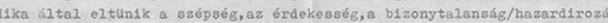

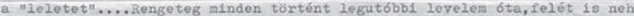

Neked is mindig szem előtt kell tartani, hogy szép és nagy szakmánk számotokra általam prezentált formája hova-tovább elveszti aktualitását. Szakmánk végsó alapjai a biochemián, ill. a histo- és cytochemián nyugszanak, lehetőség szerint quantitálandók, - ez a jövó perspektívája! Persze a mindennapos orvosi gyakorlatban valószínúleg még soká megmarad a kórszövettani diagnostica gyors és gyakorlatilag kielégítő értéke, de „tudományt csinyálni” e régi alapokon már igen nehéz.

Engem személy szerint némileg elbúsít hogy az új, quantitatív methodika által eltünik a szépség, az érdekesség, a bizonytalanság/hazardírozás öröme, mondhatnám a müvészi elem. Valójában egy magamfajta, idejétmúlt pathologus is úgy dolgozik mint egy flow-through cytophotometer. Az ötvenegy évi tapasztalat nyomán betáplálódtak a saját computerembe a malignitás, atypia, a specificitás, stb. adatai, csak lassabban, nem gépi pontossággal, közben véleményt is változtatva müködik és adja ki a végén a szalag helyett a „leletet”...

Az elmúlt 30+ év során a kórszövettanban és pathologiában valóban forradalmi változások mentek végbe, amikről sokan sokat írtak. A klasszikus patológus világa és a „Z” generáció látásmódja közötti különbséget a fenti soroknál frappánsabban, pontosabban, érzékletesebben leíró megfogalmazással azóta sem találkoztam. Azt viszont, hogy eltűnőben a szépség és művészet, naponta átélem.

A dolgok legmélyébe hatoló tekintet felejthetetlen sajátsága volt. Mihály mondta róla: „Nagyon messzire tudott nézni.” Talán, mint Zarathustra a hegy csúcsáról, vagy a Magányos cédrus a környező tájra, de gondolhatunk Rilke viharral dacoló óriás fájára is.

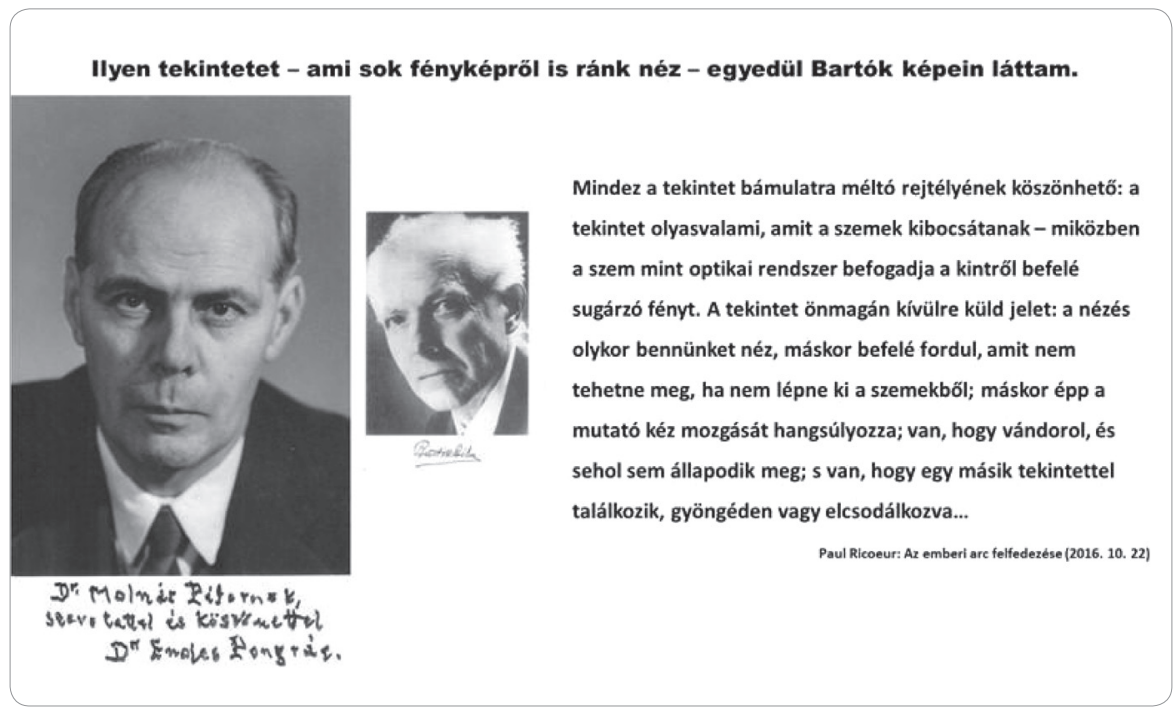


Boehm meghatározása ${ }^{31}$ - „a kép értelme az elemeket artikuláló látás dinamikus teremtöaktusából származik" - kiválóan leírja a tradicionális, analógiásan megvalósuló pathologus gondolkozást. Endes tudta és tanította, hogy az esztétikai ${ }^{32}$ élmény nélküli lét: szegényes! Biztosan egyetértett volna Fűzfa Balázs véleményével: „Irodalom nélkül lehet élni, csak nem érdemes." "33 Ezzel kapcsolatos élményem, hogy szakvizsgára jelentkezésemkor megkérdezte tőlem, hogy olvastam-e a Gullivert, a Kazohinia című Szathmári Sándor-regényt és az „Iskola a határon”-t? Mikor kiderült, hogy nem, azt kérdezte: „És mondja, Kolléga úr, maga akar kórbonctanból szakvizsgázni?”

Nem érdektelen, de ennek az írásnak kereteit meghaladja annak taglalása, hogy a kórtörténet, a boncjegyzőkönyv és a regény (mindegyikük „humanitarian narrative”) szinkron jelentkeztek az emberi civilizáció színpadán. ${ }^{34}$ Endes számára az írás esztétikai alkotómunka volt a hivatkozott definíció legszigorúbb értelmében. Öt kiadást megért, folyamatosan korszerủsített tankönyve a szabatos szaknyelvhasználat örök mintaképe, máig haszonnal forgatható, a magyar nyelven valaha megírt makroszkópos és klasszikus fénymikroszkópos pathologiai művek között csúcsteljesítmény.

Intézetvezetôi tevékenységének utolsó éveiben része lehettem annak a legfiatalabb, még nem szakorvos (mai szóval rezidens) csoportnak, akikkel a róla elterjedt képtől eltérő módon sokszor kifejezetten oldott kapcsolatba került. Az Endes lakás felett elhelyezkedő szobákban dolgoztunk, nem volt ritka, hogy meglátogatott minket. (Nota bene! Az sem, hogy este feltelefonált, hogy „ne trappoljanak, kérem!') Mikó Tivadar volt köztünk a legidősebb. Én közvetlenül tőle tanultam meg a szakma alapjait, „cserébe" megismertettem a „se nem pörkölt, se nem paprikás ételek” titkaival. Ezek közül a későbbiekben az intézeti összejöveteleken, kirándulásokon közkedveltté vált makói toros disznó fözése rituális jelentőséget kapott. Bodolay Edit, Nagy Attila és kisvártatva Thomázy Vilmos tartozott ehhez a társasághoz.

31 Gottfried Bовнм, „A képi érzelem és az érzékszervek”, in Kép, fenomén, valóság, szerk. Bacsó Béla, ford. Poprády Judit (Budapest, 1980), 242-253.

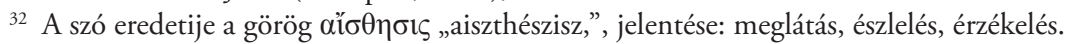

33 Csesztvén tartott „Arany János”-emlékelőadás, illetve Fưzfa Balázs, Szavak és szóközök (Savaria University Press, 2017).

${ }^{34}$ T. W. Laqueur, „Bodies, Details, and the Humanitarian Narrative”, in The New Cultural History, ed. Lynn Hunt (University of California Press, 1989). 


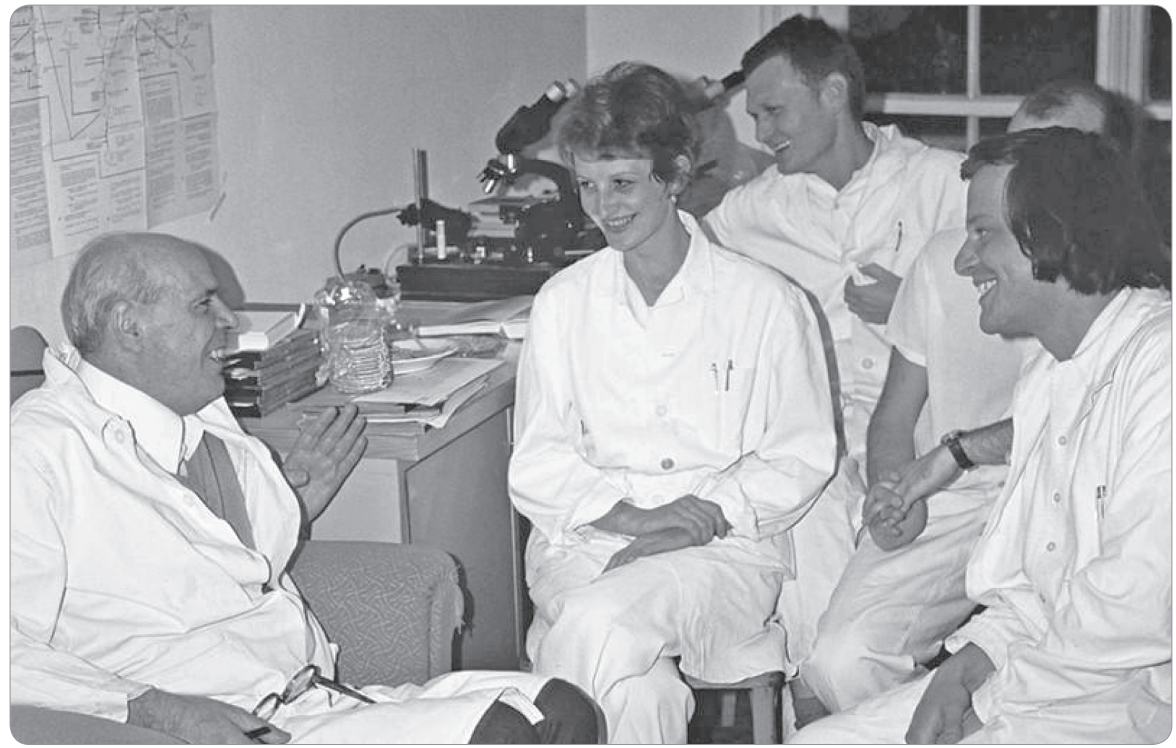

Látogatás a II. emeleti csapatnál: Endes, Bodolay, Mikó, Molnár, takarásban Nagy Attila

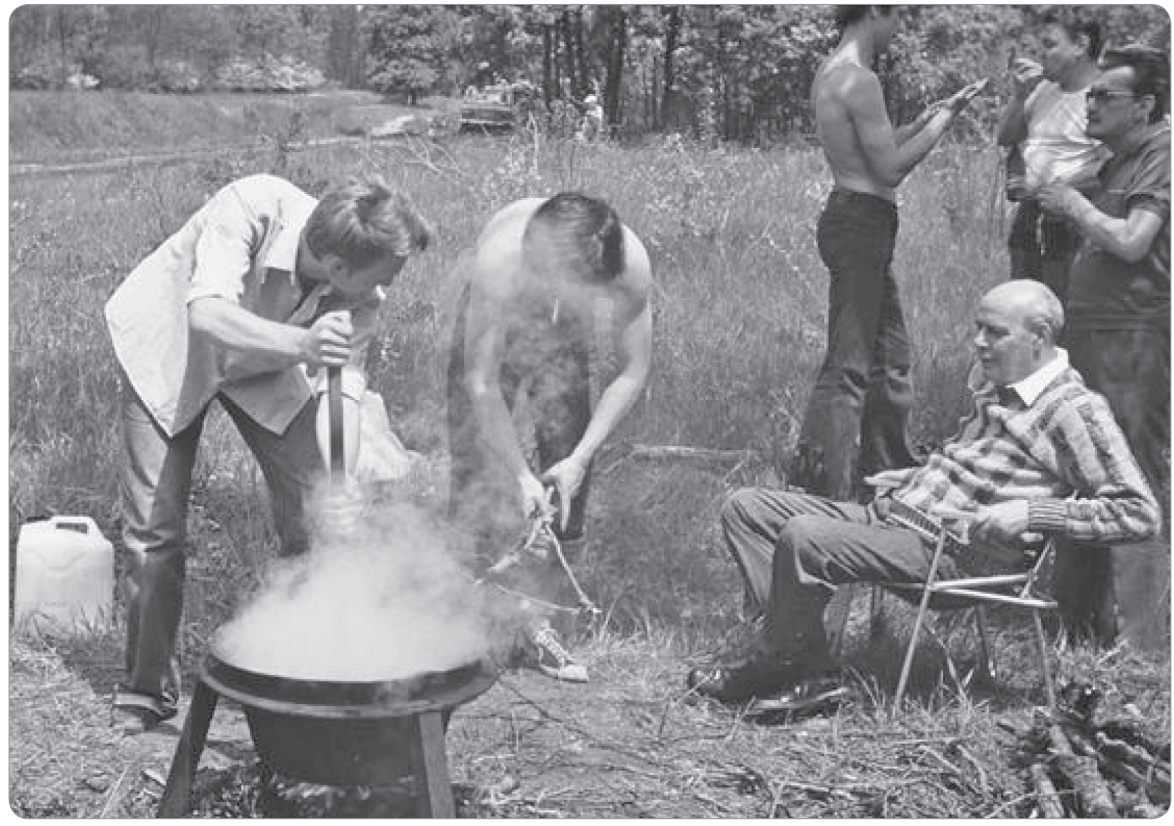

Makói toros disznó à la Mikó (kezében fakanállal).

A füstben Molnár, a háttérben Thomázy Vilmos és Szinay Gyula.

Endes látható érdeklödéssel figyeli a müveletet. Egyike a gyakori Vekeri-tónál tett biciklis kirándulásoknak 
1978-ban az intézet vezetését Gomba Szabolcs vette át. Gomba színes egyéniség, a hallgatók kedvenc oktatója volt, számos nyelven értő, olvasott, a képzőművészetekben igen járatos, felkészült szakemberként sikeresen megoldotta, hogy nem lett nagy elődje epigonja. Állítólag Endes unszolására (quasi az utódlást biztosítandó) lett az MSZMP tagja, idővel - sajnos - ezt a szerepet túl lelkesen "játszotta”. Az intézetnek nem tett jót, hogy vállalta az oktatási rektorhelyettesi feladatokat és az a tény, hogy soha nem vállalt semmilyen konfrontációt. Szakmailag nagy érvágás volt Szokol Miklós korai halála, Mikó Tivadar, Nagy Attila és Thomázy Vilmos távozása. Endes számára nagy megrázkódtatást jelentett, mikor Gomba előzetes egyeztetés nélkül, egy 3/1/10-es megbeszélésen bejelentette, hogy a továbbiakban csak az ő engedélyével lehet Endeshez konzultációs kéréssel fordulni. Ennek alapvetően egy bürokratikus minisztériumi rendelet volt az oka, de Gomba ez esetben sem vállalt semmilyen konfliktust senkivel, Endes számára viszont ez a döntés semmiképp nem hordozott salamoni értéket, mélyen megbántódott és joggal. Hallatlan pazarlás volt annak még a gondolata is, hogy mindaz a tudás, tapasztalat, bölcsesség, ami egy hosszú és kemény munkával töltött élet során Endes fejében felhalmozódott, kihasználatlan maradjon. Endes levélben részletesen beszámolt minderről és arról is, hogy Nagy Attila továbbra is konzultál vele. Szerencsére, hazaérkezésem után, én is ezt tettem, nagy hasznomra vált.

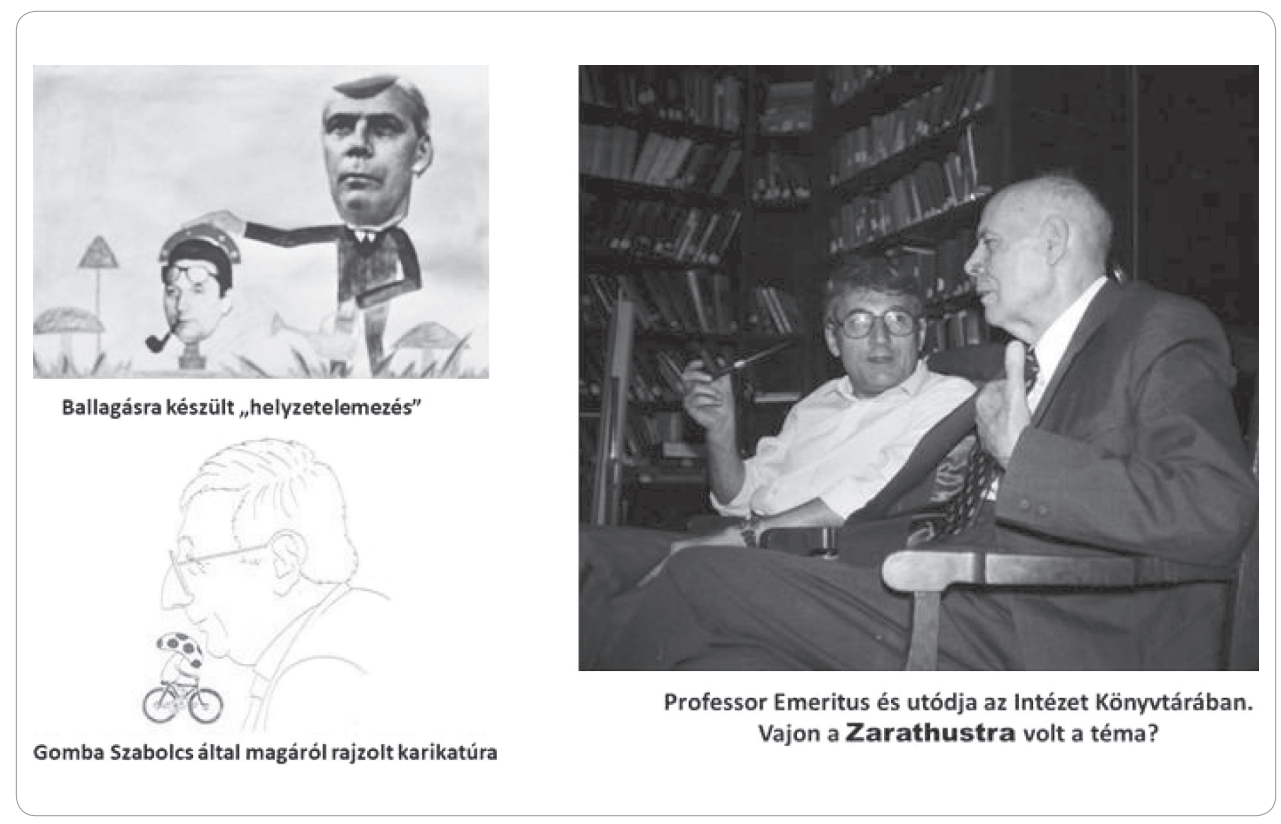

A „professor emeritus” státusz eredményeként Endeséknek ki kellett költözniük az intézetből, a II. sz. tanári villába kerültek. Endes élete legutolsó szakaszáig rendszeresen bejárt az intézetbe, de azok a levelek, melyeket az USA-ba küldött nekem, gazdagon 
illusztrálják, hogy egyre megkeseredettebb lett. Ezzel párhuzamosan kettőnk viszonya egyre mélyült.

\section{$1980 . I .21$.}

Kedves latal Barátom,-volna a megszólfitás, ha a mult század romantikus szakaszában élnénik, de ĺgy egyszerübben, Kedves pétemek szól/1tlak.äỏsänöm

Kedves Fiatal barátom, - volna a megszólítás, ha a mult század romantikus szakaszában élnénk, de így egyszerübben, Kedves Péternek szólítalak.

Leveleiben, illetve a tanári villában egyre sürübben zajló találkozásainkkor sokszor meglepett, hogy korábbi zárkózottsága eltűnt, feltárulkozott egy nagyon esendő, szenvedő, mélyen érző, engem valóban barátként kezelö, öregségében kiszolgáltatott ember. Korábban is tudott nagy meglepetésekkel szolgálni. Erre remek példa, mikor arra kért, hogy szombat délelőttönként társulhasson a piaci trabantos beszerző körutakhoz, ami Édesanyámmal hosszú éveken keresztül kedvenc időtöltésünk volt. Endes és a Trabant méretei között szembeötlő volt a szülészek által „relativ téraránytalanság”-nak nevezett viszony. A kofákkal folytatott vidám alkudozások hangulatának kevés nyoma maradt a villabéli estéken.

Egyetlen nagy tanulság azért jó, ha megmarad Benned, majd sokkal, de sokkal későbbre, amikor már Neked is módod lesz másokkal jót tenni. Jegyezd meg - azt soha nem bocsájtják meg az embernek, ha valakivel jót tett. Ez olyan, szinte fizikai törvényszerüség, ami alól csak igen kevés kivétel van.

Egyre többet panaszkodott megromlott egészségi állapota miatt. Ez eleinte groteszk volt, hiszen a panaszok között az is szerepelt, hogy $50 \mathrm{~km}$ biciklizés után (!) elfárad. Nagyon megviselte, hogy feleségének komoly szívpanaszai támadtak és saját (az életkorából adódóan elkerülhetetlen) fizikai hanyatlása egyre növekvő lelki gondokkal (céltalanság, kedvetlenség, kívülálló számára sokszor nehezen érthető önmarcangolás) társult. 


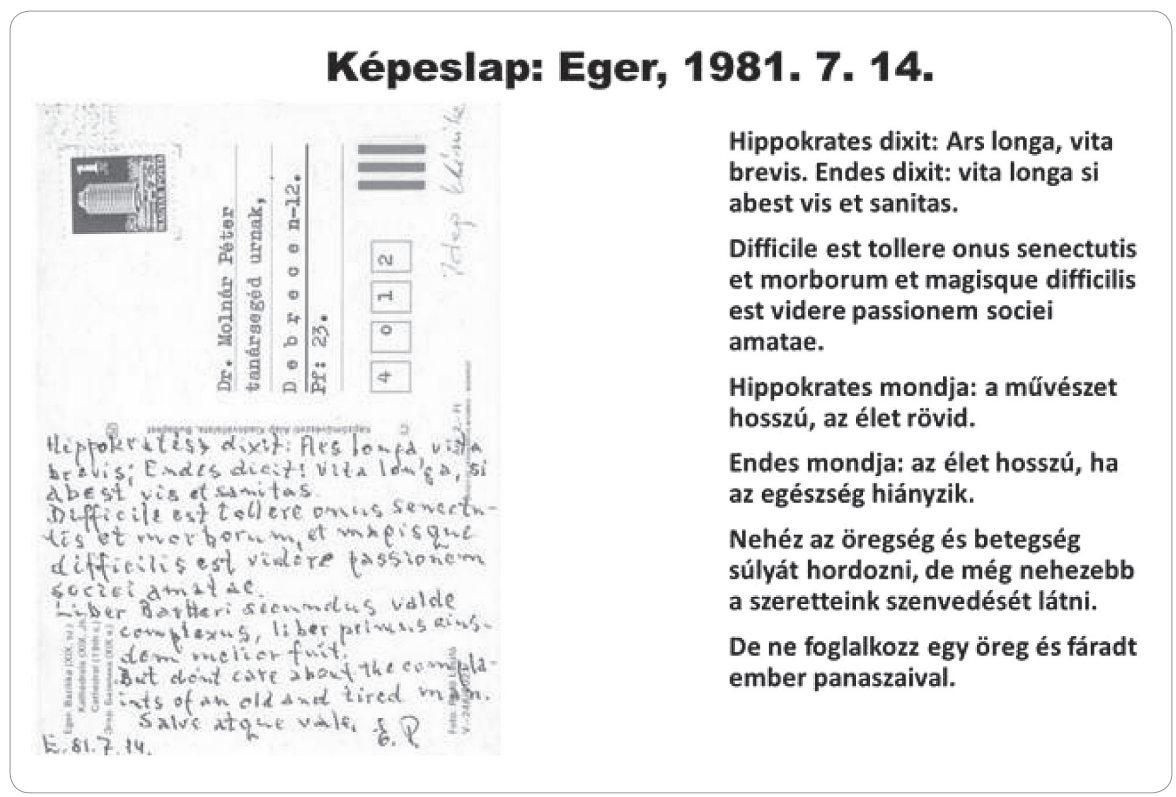

A legsúlyosabb csapás 1988. március 9-én érte: meghalt a felesége, amit soha nem tudott feldolgozni, végleg egyedül maradt. A kötelezően vörösborral kevert pezsgővel „ízesített” estéken egyre gyakrabban Beethoven „vette át a szót” - nem volt szükség annak fejtegetésére, hogy a zenei mintázatok olyan létsíkok üzeneteit közvetítik, melyek másként nem tolmácsolhatók. Beethoven késői vonósnégyesei akkor váltak kedvenceimmé. Bartók színpadi müveit nagyon sokszor hallgatta. Egyszer azt írta (de soha nem magyarázta meg), hogy kettejük kapcsolatában „Gyuri volt a Kékszakállu’”.
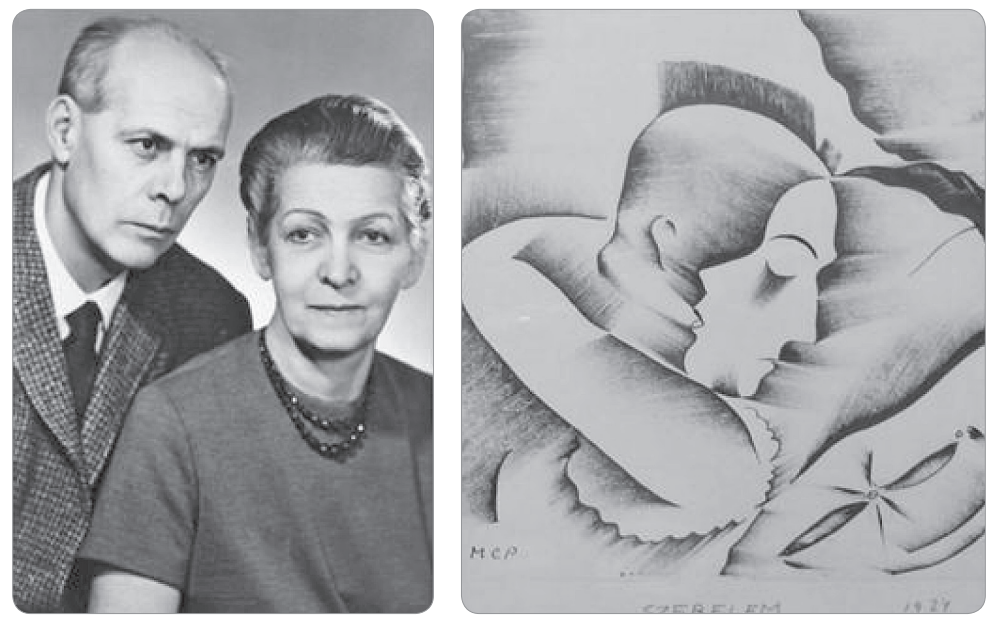

Kettejük viszonyát Molnár C. Pál müve (j. o.) remekül tükrözi. 
En az, aki voltam, csak Gyurival, o mellette, az o segiteogovel voltan és az of eltilntível az ên akkori lényem is eltuint.

Dear yeter, the so:to of tals letter io as jollow :" It rould de Detter not-to de -1ta ker, than to be aione.

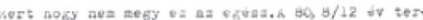

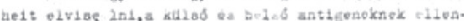

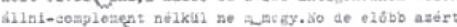

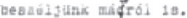

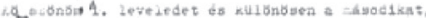

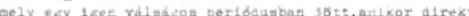

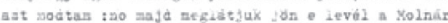

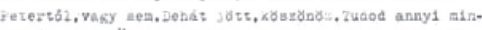

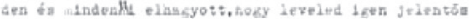
voit aderoma.

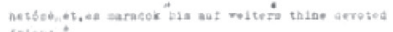

irieno.

Petrogen, Cun

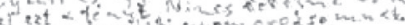

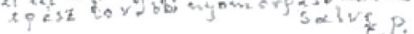

Én az, aki voltam, csak Gyurival, ర̋ mellette, az Ő segítségével voltam és az ố eltüntével az én akkori lényem is eltünt.

Dear Peter, the motto of this letter is as follows: „It would be better not-to be with Her, than to be alone."

Mert hogy nem megy ez az egész. A 80 8/12 év terheit elviselni, a külsó és belső antigeneknek ellenállni - complement nélkül nem megy. No de elôbb azért beszéljünk másról is. Köszönöm a leveledet és különösen a másodikat, mely igen válságos periódusban jött, amikor direkt azt mondtam: no majd meglátjuk jön e levél a Molnár Pétertöl, vagy sem. De hát jött, köszönöm. Tudod annyi minden és mindenki elhagyott, hogy leveled igen jelentös volt a számomra.

....és maradok „bis auf weiters thine devoted friend." PS. 89. III. 6. 1988. márc. 9-én halt meg Gyuri és egyre nehezebben viselem el ez a tényt. Nincs értelme az én egész további nyomorgásomnak.

Salve

E.P.

Ezt követően is naponta megjelent az intézetben. Én sok nehéz esetben kértem a tanácsát, a metszetek továbbra is felvidították. Utolsó közleményének megjelenését nem érhette meg. Jellemző módon ez is egy olyan eset megoldását tartalmazza, amihez az ő szívós, kitartó, analitikus hozzáállása (az „esztétikus” megközelítés) elengedhetetlen volt. Számtalan téka ${ }^{35}$ metszet fáradhatatlan vizsgálata hozta a megfejtést. Ehhez kiváló minőségü metszetekre volt szükség, amit Besenyei Mária biztosított. Endes Besenyei Máriát is tanítványának tekintette, ő az, aki a Mester szerteágazó és mára pótolhatatlan hisztotechnikai tapasztalatait a gyakorlat szintjén őrzi. Kapcsolatuk messze felülemelkedett a metszetkészítés és adequat (ami ebben az esetben szintén esztétikai kategóriát jelent) szöveti festések alkalmazásának szintjén.

Acta Morphologica Hungari:a $46(1-4)$, pp. 137-147(1992)

\section{CHRONIC INTESTINAL LYMPHOCYTIC MICROPHLEBITIS*}

\section{P. ENDES, P. MOLNÁR}

UNIVERSTYY MEDICAL SCHOOL OF DEBRECEN, DEPARTMENT OF PATHOLOGY, DEBRECEN, HUNGARY

(Received 16 July 1992

Accepted 13 August 1992)

The authors report two cases of a peculiar microphlebitis of the intestines, similar to that described by Saraga and Costa quite recently [5]. The patients had undergone

35 A mikroszkópos vizsgálathoz használt tárgylemezek tárolására alkalmas speciális kartontartó: egy tékába 20 tárgylemez fér. 
Ez a közlemény számos tanulsággal szolgál. Egy mára eltűnt pathologus szemléletnek állít emléket, aminek utolsó, nagy képviselője Endes Pongrác volt. Jellemző, hogy nem daganatos elváltozást tárgyal. Endes Saraga és Costa munkájának ismerete nélkül fejtette meg a kórkép lényegét. Ehhez a saját kórszövettani tapasztalatai és klinikaipathologiai ismeretei segítették. Ennek az integratív készségnek hiánya minden másnál fontosabb oka annak, hogy a klasszikus értelemben vett „kórboncolás” világszerte hanyatlásnak indult. Látványosabb és impact faktorokban ${ }^{36}$ kifizetődőbb a molekuláris és genetikai módszerek alkalmazása, elsősorban az onkopathologia területén. Egy látszólag rutinboncolás eredményének olyan jellegü értelmezése, ami a szokásos mögött a minden esetben fellelhető sajátost láttatja, mára nem vonzó feladat, véleményem szerint elsősorban azért, mert nem vagyunk kellően felkészültek. Ehhez olyan intellektus szükséges, ami a mintázatfelismerést a legmagasabb szinten képes gyakorolni. Szerencsések voltunk, mert megtanulhattuk: a „mindenséget”kell megpróbálnunk megérteni, ami persze lehetetlen, de nem szabad feladnunk. Talán tényleg boldog lehet Camus „Sisyphosa”? Endes Dsida Jenő, Reményik Sándor, Rilke verseinek idézésekor arra próbált tanítani, hogy a "mindenség” bennünk van, és ennek megközelítésekor támaszkodnunk kell a kultúra minden formájára. Csak az ilyen tudás segíthet abban, hogy kiszolgáltatott, beteg embertársainkon a tőlünk telhető legnagyobb erőfeszítéssel segíteni próbáljunk.

Életének utolsó időszakát a DOTE Urológiai Klinikáján töltötte, ahol többször meglátogattam. Visszahúzódóvá vált, egyértelműen depressziós periódusokkal küzdött. Számomra nem derült ki, hogy volt-e szervi betegsége, ami indokolta klinikai kezelését, felvételét. Halálának pontos okát nem tudom. A halálát megelőző hónapokban tanulmányúton voltam. A korábbiakkal szemben ez alkalommal már nem kaptam tőle levelet, nem tudtunk elbúcsúzni egymástól. Most, a kettős évforduló adott erre lehetőséget.

Előadásomat egy Vergilius-idézettel zártam. Ez a kettős évforduló ünnepi megemlékezésének befejezéséhez alkalmasnak tűnt.

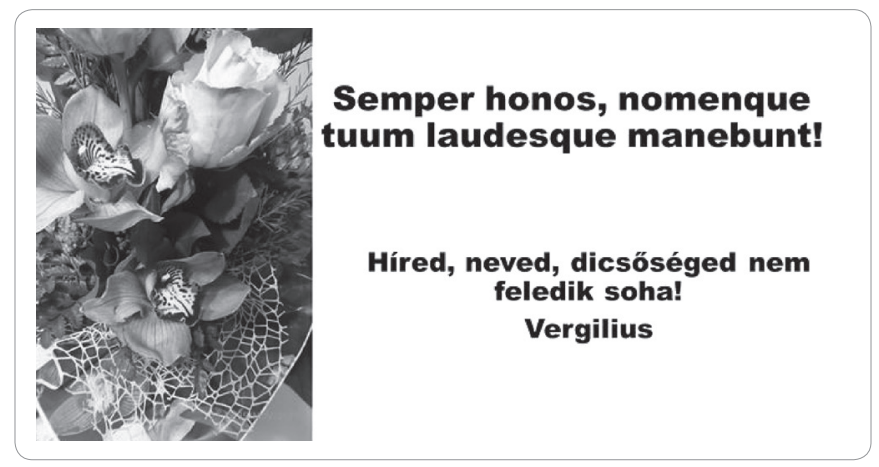

${ }^{36}$ Impact factor, IF: a legszélesebb körben elterjedt scientometriai egység, a tudományos produktivitás mérőszáma. 
Az előadás közelesen hủ prózába öntésekor annyiban szeretném a fenti idézetet kiegészíteni, hogy "jó lenne, ha így lenne”, és ehhez talán egy morzsával írásom is hozzájárulhat.

Úgy érzem, hogy az emlékezés nem lenne teljes, ha nem tartalmazná azt a képet, amely Endes Pongrác születésének 100. évfordulóján készült és szobrán kívül még három Endes látható rajta. Fiai, balról jobbra: Mihály, György és János.

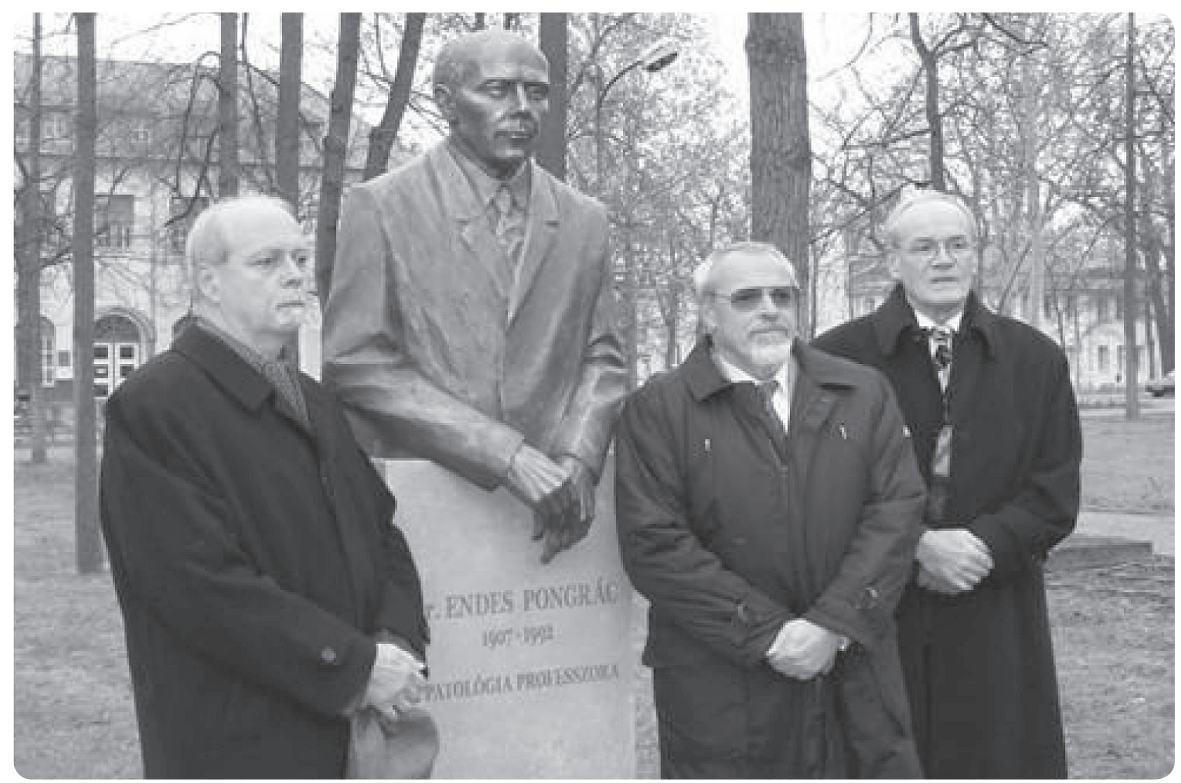

\section{Köszönetnyilvánitás}

Módis László professzor úr szorgalmazta, hogy a kettős évfordulót a Magyar Orvostörténeti Társaság és a Debreceni Egyetem Professzori Klubja közösen ünnepelje és az előadást én tartsam meg. Mátyus László dékán az ünnepség lebonyolításához minden segítséget megadott, Oláh Éva professzornő maximálisan támogatta a kezdeményezést. Nélkülük nem kerülhetett volna sor az ünnepi megemlékezésre, nagyon köszönöm. Bár rengeteg emléket őrzök Endes professzor úrról, ez az anyag csak úgy állhatott össze, hogy Endes Mihály, Endes György és Endes János nagy türelemmel állták kérdéseimet, beszéltek édesapjukról, családjukról, emlékeikről - hálás köszönet érte. Krasznai Géza Főorvos úr számos érdekes-értékes részlettel szolgált a korai Endes-időszakról.

A fényképek egy részét Besenyei Máriának és Nagy Attilának köszönöm. Attila gyermekkoráig visszanyúló emlékekkel rendelkezik, hiszen Endes Debrecenbe kerülésekor édesapja vezette az intézetet, ahol később ő is Endes tanítványaként dolgozott. Segítségéért őszinte hálával tartozom. 